\title{
JadX is a Disparate Natural Product Binding Protein
}

Andrew W. Robertson, ${ }^{\dagger}$ Stephanie M. Forget, ${ }^{\dagger}$ Camilo F. Martinez-Farina, ${ }^{\dagger}$ Nicole E. McCormick, ${ }^{\ddagger}$ Raymond T. Syvitski ${ }^{\dagger}, \S$ David L. Jakeman ${ }^{*}, \dagger, \$$

${ }^{\dagger}$ Department of Chemistry, Dalhousie University, Halifax, Nova Scotia B3H 4R2, Canada

${ }^{\S}$ Institute for Marine Biosciences, National Research Council of Canada, Halifax, Nova Scotia B3H 3Z1, Canada

${ }^{\ddagger}$ College of Pharmacy, Dalhousie University, Halifax, Nova Scotia B3H 4R2, Canada

SUPPORTING INFORMATION

Materials and Methods................................................................................................... 2

Bacterial Strains and Growth Conditions ........................................................................ 3

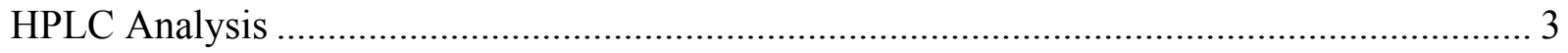

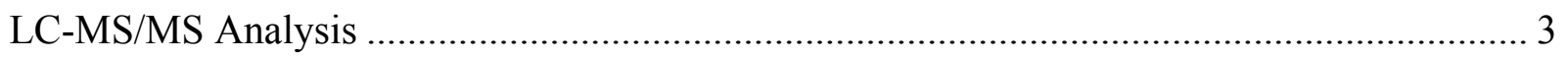

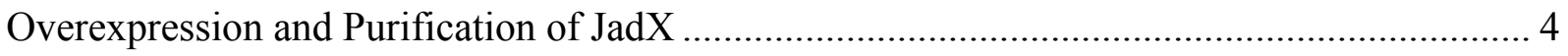

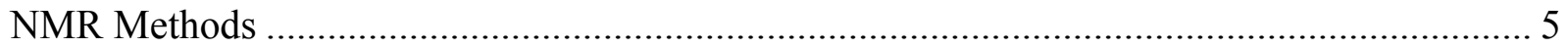

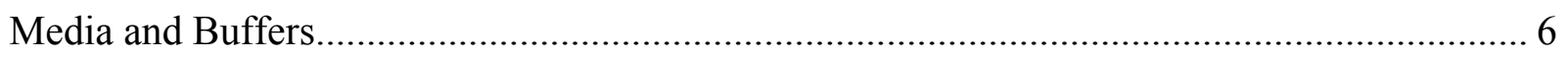

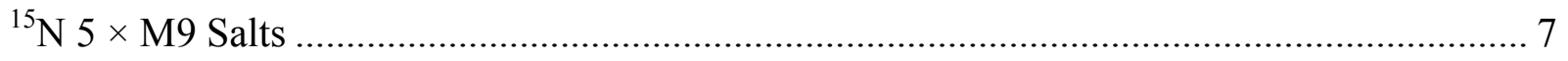

Jadomycin DS Production, Isolation and Characterization ............................................... 8

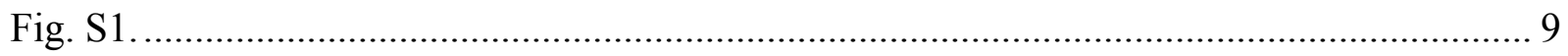

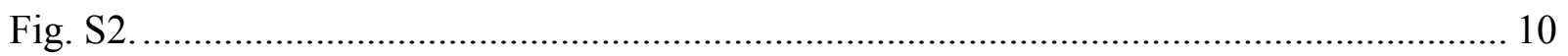

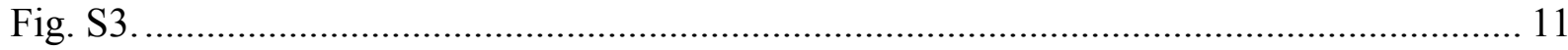

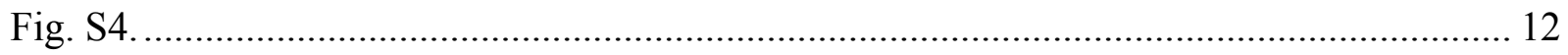

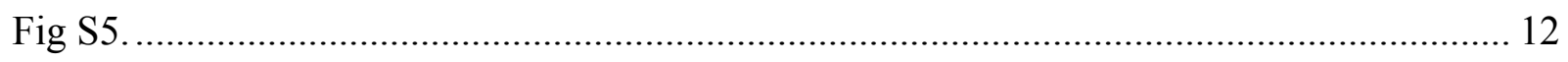

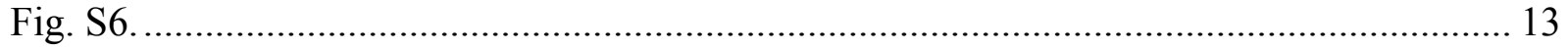

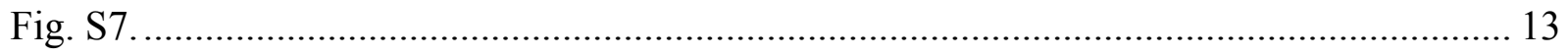

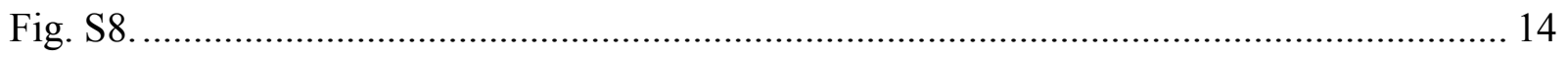

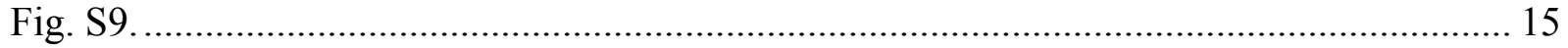

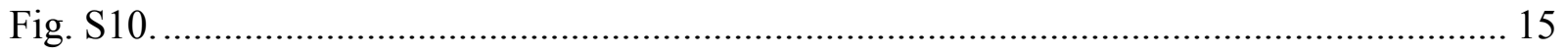

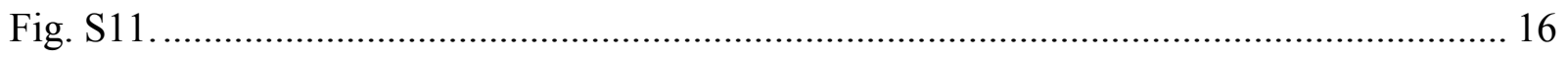

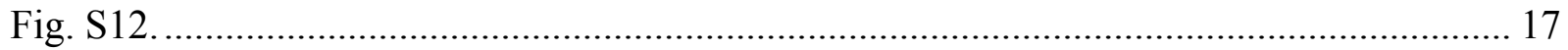

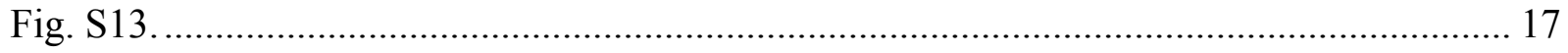

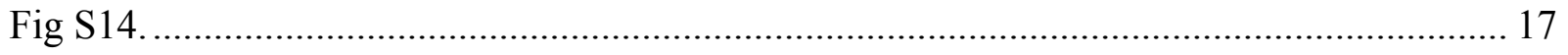

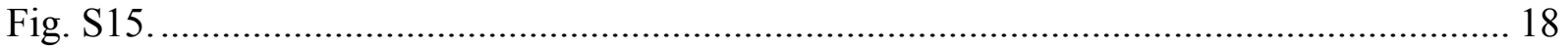

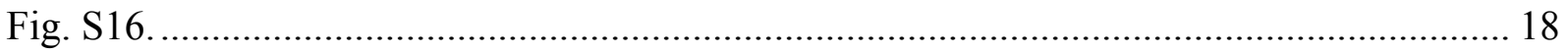


Fig. S17.

Fig. S18.

Fig. S19.

Fig. S20.

Fig. S21.

Table S1. Putative and assigned protein functions of jadomycin biosynthetic enzymes and

regulatory proteins. 23

Table S2. Jadomycin DS NMR data recorded in dPBS.................................................... 24

Table S3. Tabulated $K_{\mathrm{d}}$ values for Cm and JdDS binding JadX ....................................... 25

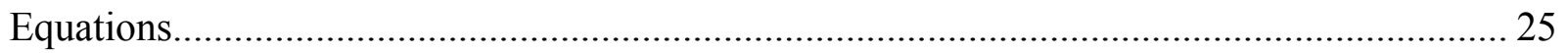

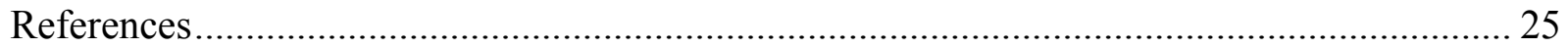

a. Department of Chemistry, Dalhousie University, Halifax, Nova Scotia Canada.

${ }^{b .}$ College of Pharmacy, Dalhousie University, Halifax, Nova Scotia B3H 4R2, Canada, Email: david.jakeman@dal.ca

\section{Materials and Methods}

All reagents were purchased from commercial sources and used without further purification unless otherwise stated. Solvents used for all jadomycin chromatographic purifications were HPLC grade. Flash chromatography was performed using a Biotage $\mathrm{SP} 1^{\mathrm{TM}}$ unit (Biotage ${ }^{\circledR}$ ) using pre-packed normal phase silica columns from SiliCycle ${ }^{\circledR}$. Glass-backed thin layer chromatography (TLC) plates (SiliCycle ${ }^{\circledR}$ ) layered with $250 \mu \mathrm{m}$ silica were used to assess purity of compounds. Preparative TLC was performed using $20 \times 20 \mathrm{~cm}$ glass-backed plates $\left(\right.$ SiliCycle $^{\circledR}$ ) layered with $1000 \mu \mathrm{m}$ or $2000 \mu \mathrm{m}$ silica. Using the appropriate solvent mixture, the TLC plates were developed, then allowed to dry, then developed and dried again. This process was repeated until good separation was observed ( 2-4 cycles). Bands of interest were scraped off the glass backing and eluted using the same solvent used for development. Size-exclusion chromatography was accomplished using Sephadex ${ }^{\text {TM }}$ LH-20 (GE Healthcare) resin. Jadomycins were dissolved in methanol and passed through Chelex ${ }^{\circledR} 100$ resin (BioRad) prior to all NMR binding experiments to ensure no aggregation due to the presence of divalent metal cations. Protein concentrations were determined by UV absorbance at $280 \mathrm{~nm}$. 


\section{Bacterial Strains and Growth Conditions}

S. venezuelae ISP5230 WT, S. venezuelae ISP5230 VS1099 (DjadW2::aac(3)IV), and S. venezuelae ISP5230 VS1085 (AjadX::aac(3)IV) spores were maintained in glycerol stock solutions at $-70^{\circ} \mathrm{C}$, and grown on MYM agar at $30^{\circ} \mathrm{C}$ for a period of $1-3$ weeks before use in $\mathrm{Jd}$ production. Production and isolation of JdDS was carried out according to the literature. ${ }^{1}$

\section{HPLC Analysis}

For HPLC analyses of growth media, $20 \mathrm{~mL}$ of growth media from the WT, $\Delta j a d W 2:: a a c(3) I V$ or $\Delta j a d X:: a a c(3) I V$ growths were passed down $2 \mathrm{~g}$ phenyl columns preconditioned with methanol. Columns were washed with $100 \mathrm{~mL} \mathrm{H}_{2} \mathrm{O}$ and material was eluted with $100 \%$ methanol. Eluent was dried down and dissolved in $4 \mathrm{~mL}$ methanol. This crude extract was then injected $(20 \mu \mathrm{L})$ into the system. HPLC analyses were performed on a Hewlett Packard Series 1050 instrument with an Agilent Zorbax $5 \mu \mathrm{m} \mathrm{Rx}-\mathrm{C} 18$ column $(4.6 \times 150 \mathrm{~mm})$. Elution of the compounds was monitored at an absorbance of $254 \mathrm{~nm}$ using an isocratic gradient of 9:1 (A:B) over 0.5 min followed by an increasing linear gradient from 9:1 (A:B) to 4:6 (A:B) over $7.5 \mathrm{~min}$, followed by an isocratic gradient of 4:6 (A:B) for an additional $2 \mathrm{~min}$. This was then followed by a decreasing linear gradient from 4:6 (A:B) to 9:1 (A:B) over 1 min, ending with an isocratic gradient of 9:1 (A:B) over 4 min (total time $15 \mathrm{~min}$; flow rate of $1 \mathrm{ml} / \mathrm{min}$ ). Buffer A was an aqueous buffer comprised of $12 \mathrm{mM} \mathrm{Bu} 4 \mathrm{NBr}, 10 \mathrm{mM} \mathrm{KH}_{2} \mathrm{PO}_{4}$, and $5 \%$ HPLC grade $\mathrm{CH}_{3} \mathrm{CN}$ ( $\mathrm{pH}$ 4.0) and B was HPLC grade $\mathrm{CH}_{3} \mathrm{CN}$. Samples were compared to a standard of pure JdDS. $\mathrm{Cm}$ spiking experiments were accomplished by spiking with purchased $\mathrm{Cm}$ to a final spiked concentration of $100 \mu \mathrm{M}$. Spiked samples were run as previously described.

\section{LC-MS/MS Analysis}

Low-resolution liquid chromatography mass spectrometry was performed using an Applied Biosystems hybrid triple quadrupole linear ion trap (Qtrap 2000) mass spectrometer with an electrospray ionization (ESI) source, in tandem with a Agilent 1100 Series HPLC equipped with a Phenomenex Kinetex $2.6 \mu \mathrm{m}$ hydrophobic interaction chromatography (HILIC) 100A column $(150 \mathrm{~mm} \times 2.10 \mathrm{~mm})$. Clarified growth media was lyophilized. Samples were dissolved appropriately (to ensure a concentration of $\mathrm{Jd}$ or $\mathrm{Cm}$ that was within the linear detectable range of the instrument) in methanol, filtered and $5 \mu \mathrm{L}$ aliquots were injected onto the column. Elution of compounds was accomplished using an isocratic gradient of (7:3) $\mathrm{CH}_{3} \mathrm{CN}: 2 \mathrm{mM}$ ammonium 
acetate in water ( $\mathrm{pH} 5.5$ ) with a flow rate of $120 \mu \mathrm{L} \mathrm{min}^{-1}$ for $10 \mathrm{~min}$. For the Jds, the instrument was used in positive mode (ESI+). For $\mathrm{Cm}$, the instrument was used in negative mode (ESI-). Enhanced product ionization (EPI) was conducted over a range of 300-900 m/z scanning for $[\mathrm{M}+\mathrm{H}]^{+}$and the appropriate Jd fragmentation. Scans were conducted using two steps, $300.0 \mathrm{amu}$ to $320 \mathrm{amu}(0.005 \mathrm{~s})$ and $300.0 \mathrm{amu}$ to $900.0 \mathrm{amu}(0.150 \mathrm{~s})$. Spectra were analyzed using Analyst software version 1.4.1 (Applied Biosystems). Peaks representing total ion count were integrated and integrals were compared to standard curves generated from pure samples to determine concentrations. All measurements were performed in triplicate.

\section{Overexpression and Purification of JadX}

jadX was amplified by PCR from $S$. venezuelae ISP5230 WT genomic DNA using primers jadX2mR 5'GGTGGTAAGCTTTCAGGAGT

GGCCCTTCGCGCCGGGG GCCTCGCCGGCGTTC-3' and jadX3mF 5'GGTGGTCATAT GACCACCACCGACCTCACCGCCGTGAC CACCACCGACGGA-3' . jadX2mR and jadX3mF introduced HindIII and NdeI restriction sites respectively (sites underlined). The amplified fragment was digested with the appropriate restriction enzymes and ligated into pET28a(+) giving pET28a $(+):: j a d X$. The plasmid was introduced, expressed and purified from E. coli DH5 $\alpha$. The plasmid was then introduced into E. coli BL21( $\lambda$ DE3). Transformed cells were grown overnight on LB-agar plates supplemented with kanamycin $\left(50 \mu \mathrm{g} \mathrm{ml}^{-1}\right)$. Transformants were grown overnight in LB medium supplemented with kanamycin $\left(50 \mu \mathrm{g} \mathrm{ml}^{-1}\right)$ on a rotary shaker $(250 \mathrm{rpm})$ at $30^{\circ} \mathrm{C}$. Growths were performed on a $2 \mathrm{~L} \mathrm{scale}(8 \times 250 \mathrm{~mL}$ in $1 \mathrm{~L}$ flasks $)$. A $2.5 \mathrm{~mL}$ aliquot of inoculum from the overnight culture was added to $250 \mathrm{~mL} \mathrm{LB}$ medium supplemented with kanamycin $\left(50 \mu \mathrm{g} \mathrm{ml}^{-1}\right)$. Bacteria were grown in the fresh media at $30^{\circ} \mathrm{C}$ until an $\mathrm{OD}_{600}$ of $\sim 0.6$ was reached. A $250 \mu \mathrm{L}$ aliquot of a 1 M IPTG stock solution was added to the media to a final concentration of $1 \mathrm{mM}$. Cultures were cooled to $17^{\circ} \mathrm{C}$ and incubated at that temperature for $20 \mathrm{hr}$. The cells were pelleted by centrifugation $\left(4000 \times \mathrm{g}, 4^{\circ} \mathrm{C}, 60 \mathrm{~min}\right)$ and the supernatant was decanted. Cells were suspended in $20 \mathrm{~mL}$ of lysis buffer (lysis buffer: $3 \mathrm{~mL}$ sterile glycerol, $1 \mathrm{~mL} 10 \% 100 \times$ Triton, $16 \mathrm{~mL}$ of binding buffer [300mM NaCl; $20 \mathrm{mM}$ Tris $\bullet \mathrm{HCl}, 25 \mathrm{mM}$ imidazole; $\mathrm{pH}=8.0])$ per $1 \mathrm{~L}$ of growth media. Lysozyme $(0.5 \mathrm{mg} / \mathrm{mL})$ and

DNase $(1 \mu \mathrm{g} / \mathrm{mL})$ were added, and the solution was mixed on ice for 30 minutes followed by sonication $(5 \times 5$ s pulses; amplitude 50\%; Autotune High Intensity Ultrasonic Processor, 750 
W). The crude lysate was centrifuged at 13,000 RPM for 15 minutes at $4^{\circ} \mathrm{C}$. The supernatant then loaded onto a HiTrap $5 \mathrm{ml}$ Chelating HP NTA-Ni ${ }^{2+}$ affinity column (Amersham Biosciences) and purified at $4{ }^{\circ} \mathrm{C}$ using a Fast Protein Liquid Chromatography (FPLC) (AKTA purifier 10). A step-wise gradient of imidazole $(25-250 \mathrm{mM})$ was applied and elution of the protein was monitored by UV absorbance $280 \mathrm{~nm}$. The presence of JadX was determined by sodium dodecyl sulfate polyacrylamide gel (SDS-PAGE) analysis of the fractions. Those containing JadX were pooled and concentrated to $\sim 2.5 \mathrm{~mL}$ by ultrafiltration $\left(3000 \times \mathrm{g}\right.$ at $4^{\circ} \mathrm{C}$, in Vivaspin-20, 10,000 MWCO tubes, VivaScience Sartorious group). Buffer exchange was then performed into PBS buffer (pH 7.6) using a PD-10 desalting column (GE Healthcare). The solution was concentrated again to $2.5 \mathrm{~mL}$ by ultrafiltration and desalted again into PBS buffer ( $\mathrm{pH}$ 7.6) to ensure removal of all Tris contamination. For ${ }^{1} \mathrm{H}-{ }^{1} \mathrm{H}$ HSQC studies, buffer exchange was performed into PBS buffer $(\mathrm{pH}$ 6.6). Protein concentrations were determined using spectrophotometric analysis $\left(\varepsilon_{280}=22460 \mathrm{M}^{-1} \mathrm{~cm}^{-1}\right)$. Using the same plasmid and bacterial strains,

${ }^{15} \mathrm{~N}$-labeled ${ }^{15} \mathrm{~N}$-JadX was overexpressed using minimal media containing ${ }^{15} \mathrm{~N}$-ammonium chloride according to literature precedent ${ }^{2}$ and purified in the same manner as the unlabeled $\operatorname{JadX}$.

\section{NMR Methods}

All NMR spectra were recorded using a Bruker AV-III $700 \mathrm{MHz}$ Spectrometer $\left({ }^{1} \mathrm{H}\right.$ : $700 \mathrm{MHz}$, ${ }^{13} \mathrm{C}: 150 \mathrm{MHz}$ ) equipped with an ATMA $5 \mathrm{~mm}$ or $1.7 \mathrm{~mm}$ TCI cryoprobe, located at the Canadian National Research Council Institute for Marine Biosciences (NRC-IMB) in Halifax, Nova Scotia unless otherwise stated. To prepare dPBS buffer, PBS buffer of the appropriate $\mathrm{pH}$ was lyophilized and dissolved in an equal volume of $\mathrm{D}_{2} \mathrm{O}$. All initial WaterLOGSY NMR spectra used for ligand screening purposes were recorded in 90\% PBS, 10\% dPBS (pH 7.6) buffer. All WaterLOGSY and ${ }^{15} \mathrm{~N}-{ }^{1} \mathrm{H}$ HSQC experiments used for $K_{\mathrm{d}}$ estimations were recorded in $85 \%$ PBS, $10 \%$ dPBS, 5\% DMSO-d $\mathrm{d}_{6}$ (pH 7.6 and 6.6 respectively). Appropriate solvents used in each case can be found with the accompanying supplemental NMR-spectra. Chemical shifts ( $\delta)$ were given in ppm, and calibrated to residual solvent peaks $\left(\mathrm{D}_{2} \mathrm{O} 4.79 \mathrm{ppm}\right.$ or DMSO in water $2.71 \mathrm{ppm}){ }^{3}$ 


\section{Media and Buffers}

Except where noted, all media were sterilized by autoclaving at $120^{\circ} \mathrm{C}$ for 20 minutes prior to use.

Maltose Yeast Malt Extract (MYM) Media (autoclaved)

Maltose $(0.4 \% \mathrm{w} / \mathrm{v})$,

Yeast extract $(0.4 \% \mathrm{w} / \mathrm{v})$,

Malt extract $(1 \% \mathrm{w} / \mathrm{v}) ; \mathrm{pH} 7.0$

MYM agar

MYM supplemented with 1.5\% agar

Minimal Salt Media (MSM)

$\mathrm{MgSO}_{4}(0.4 \mathrm{~g})$,

MOPS (1.9 g),

Salt solution $\left(9 \mathrm{~mL} / \mathrm{L}\right.$ of $1 \% \mathrm{w} / \mathrm{v} \mathrm{NaCl}$ and $\left.1 \% \mathrm{w} / \mathrm{v} \mathrm{CaCl}_{2}\right)$

$\mathrm{FeSO}_{4} \cdot 7 \mathrm{H}_{2} \mathrm{O}(4.5 \mathrm{~mL} / \mathrm{L}$ of $0.2 \% \mathrm{w} / \mathrm{v})$

Trace mineral solution $(4.5 \mathrm{~mL} / \mathrm{L}), \mathrm{pH} 7.5$

The trace mineral solution contained, per litre: $\mathrm{ZnSO}_{4} \cdot 7 \mathrm{H}_{2} \mathrm{O}(880 \mathrm{mg}), \mathrm{CuSO}_{4} \cdot 5 \mathrm{H}_{2} \mathrm{O}(39$ $\mathrm{mg}), \mathrm{MnSO}_{4} \cdot 4 \mathrm{H}_{2} \mathrm{O}(6.1 \mathrm{mg}), \mathrm{H}_{3} \mathrm{BO}_{3}(5.7 \mathrm{mg})$, and $\left(\mathrm{NH}_{4}\right) 6 \mathrm{Mo}_{7} \mathrm{O}_{24} \cdot 4 \mathrm{H}_{2} \mathrm{O}(3.7 \mathrm{mg})$.

Minimal Salt Media (MSM) With Amino Acid

MSM medium supplemented with $60 \mathrm{mM}$ of amino acid.

TE25 buffer (for lysis during genomic DNA extraction)

Tris- $\mathrm{HCl} \mathrm{pH} 8 \quad 25 \mathrm{mM}$

EDTA pH $8 \quad 25 \mathrm{mM}$

Sucrose $\quad 0.3 \mathrm{M}$

$2 \times$ Kirby mix (for genomic DNA isolation)

TPNS (or SDS) $\quad 2 \mathrm{~g}$

Sodium 4-aminosalicilate $\quad 12 \mathrm{~g}$

$2 \mathrm{M}$ Tris $\mathrm{HCl} \mathrm{pH} 8 \quad 5 \mathrm{~mL}$

Equilibrated phenol $\mathrm{pH} 8 \quad 6 \mathrm{~mL}$

Distilled water to $\quad 100 \mathrm{~mL}$

LB broth (E. coli growths)

Tryptone $\quad 10 \mathrm{~g}$ 
Yeast Extract $\quad 5 \mathrm{~g}$

$\mathrm{NaCl} \quad 10 \mathrm{~g}$

Dissolved in $1 \mathrm{~L}$ distilled water

pH 7.0

LB agar (E. coli growths)

LB broth supplemented with $1.5 \%$ agar

$5 \times$ M9 Salts (autoclaved)

$\begin{array}{ll}\mathrm{KH}_{2} \mathrm{PO}_{4} & (15.0 \mathrm{~g} / \mathrm{L}) \\ \mathrm{NaHPO}_{4} \cdot 7 \mathrm{H}_{2} \mathrm{O} & (64.0 \mathrm{~g} / \mathrm{L}) \\ \mathrm{NaCl} & (2.5 \mathrm{~g} / \mathrm{L}) \\ \mathrm{NH}_{4} \mathrm{Cl} & (5.0 \mathrm{~g} / \mathrm{L})\end{array}$

Dissolved in $1 \mathrm{~L}$ distilled water

pH adjusted to 7.2 with $\mathrm{NaOH}$

${ }^{15} \mathrm{~N} 5 \times$ M9 Salts (autoclaved)

$5 \times$ M9 salts solution with ${ }^{15} \mathrm{~N}$-ammonium chloride $\left({ }^{15} \mathrm{NH}_{4} \mathrm{Cl}\right)$ instead of unlabeled $\mathrm{NH}_{4} \mathrm{Cl}$.

${ }^{15} \mathrm{~N}-$ Minimal growth medium $(1 \mathrm{~L})$

${ }^{15} \mathrm{~N} 5 \times$ M9 Salts $(200 \mathrm{~mL})$ autoclaved separately

D-glucose $(20 \% \mathrm{w} / \mathrm{v})(20 \mathrm{~mL})$ filter sterilized using $0.2 \mu \mathrm{m}$ filter disks

$100 \times$ Basal Medium Eagle Vitamin Solution $(10.0 \mathrm{~mL})$

$1 \mathrm{M} \mathrm{MgSO}_{4}(2.0 \mathrm{~mL})$ autoclaved separately

$1 \mathrm{M} \mathrm{CaCl}_{2}(0.1 \mathrm{~mL})$ autoclaved separately

$\mathrm{H}_{2} \mathrm{O}(770 \mathrm{~mL})$ autoclaved separately

Mixed aseptically and divided into $4 \times 250 \mathrm{~mL}$ fractions in sterile $1 \mathrm{~L}$ flasks.

Phosphate Buffered Saline (PBS) Buffer (Filter Sterilized)

$\mathrm{NaH}_{2} \mathrm{PO}_{4} \cdot \mathrm{H}_{2} \mathrm{O}(6.9 \mathrm{~g} / \mathrm{L}, 50 \mathrm{mM})$

$\mathrm{NaCl}(8.482 \mathrm{~g} / \mathrm{L}, 145 \mathrm{mM})$

Dissolved in $1 \mathrm{~L}$ distilled $\mathrm{H}_{2} \mathrm{O}$

$\mathrm{pH}$ was adjusted to 7.6 or 6.6 (as needed) with $\mathrm{NaOH}$ solution (1 M). 
Solutions were filter sterilized by passing through a $0.22 \mu \mathrm{m}$ Millipore Durapore $\mathbb{R}$ Membrane filters.

dPBS Buffer

PBS buffer of a known $\mathrm{pH}$ (pH 7.6 or 6.6) was lyophilized for $48 \mathrm{hrs}$ and dissolved in an equal volume of $\mathrm{D}_{2} \mathrm{O}$.

\section{Jadomycin DS Production, Isolation and Characterization}

S. venezuelae ISP5230 VS1099 was grown under standard conditions in MSM minimal media supplemented with D-serine $(60 \mathrm{mM})$ in 2 L batches.(30) Production of JdDS was initiated by ethanol shock, and growths were monitored spectrophotometrically over a 48 hour incubation period as described. After 24 hours, the $\mathrm{pH}$ of the media was readjusted to $\mathrm{pH}$ 7.5. Cells were removed via filtration through Whatman No. 5 filter paper, followed by $0.45 \mathrm{~mm}$ then $0.22 \mathrm{~mm}$ Millipore Durapore ${ }^{\circledR}$ membrane filters. The clarified growth media was passed through a reversed-phase SiliCycle ${ }^{\circledR}$ phenyl column $(70 \mathrm{~g})$, and washed with distilled water until flow through was colorless. The remaining material was eluted with $100 \%$ methanol and dried in vacuo. The crude mixture was purified using an $80 \mathrm{~g}$ silica column pre-conditioned with dichloromethane (DCM). The material was eluted using a $30 \mathrm{~mL} / \mathrm{min}$ flow rate collecting $9 \mathrm{~mL}$ fractions. Purification was accomplished using a linear gradient system from $0 \%$ to $100 \%$ methanol in DCM over $50 \mathrm{CV}$. The fractions containing JdDS pooled and dried in vacuo. The sample was dissolved in minimal 10\% methanol in DCM and loaded onto a preparatory TLC plate and developed in the same solvent system. Silica containing JdDS was scraped from the plate and the compound was eluted using 10\% methanol in DCM and dried in vacuo. A second preparative TLC was run on the crude natural product (5:5:1 $\left.\mathrm{CH}_{3} \mathrm{CN}: E t O A c: \mathrm{H}_{2} \mathrm{O}\right)$. Solvent was then removed in vacuo to yield the purified jadomycin as a purple solid in a yield of $51 \mathrm{mg} / \mathrm{L}$. The compound was successfully characterized by NMR spectroscopy and LC-MS/MS. Pure samples were prepared and served as standards for NMR-binding studies and for LC-MS/MS production curves. NMR data in APBS can be found in Table S2. 


\section{Fig. S1.}

Structures of the natural products azicemicin, geldanamycin, herbimycin, kinamycin, and methylenomycin whose biosynthetic gene clusters code for a JadX homolog.<smiles>COc1c(O)cc2c(OC)c3c(c(O)c2c1O)C(=O)CC1CC(O)(C2CN2C)CC(=O)C31O</smiles>

Azicemicin A<smiles>CC(=O)O[C@H]1C2=C(C(=O)c3cccc(O)c3C2=O)[C@@H]([N+]#N)C2=C1[C@H](O)[C@](C)(OC(C)=O)[C@H]2O</smiles>

Kinamycin A

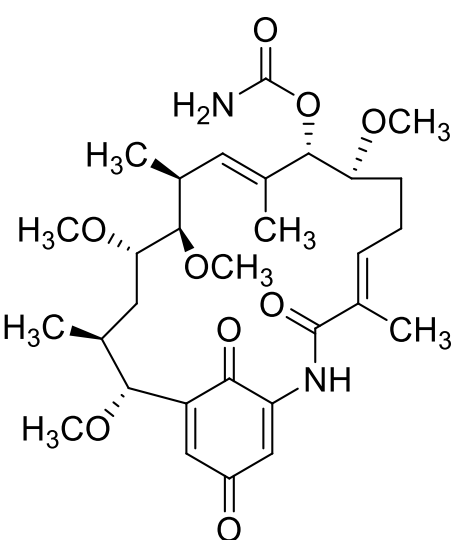

Herbimycin A

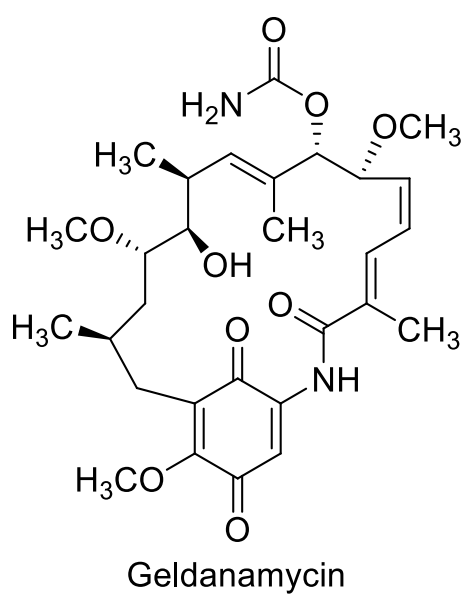

Methylenomycin A 


\section{Fig. S2.}

Multiple sequence alignment of JadX versus various homologous proteins using Clustal W. Highly conserved amino acids are bolded and underlined. The proteins and producing organisms are: JadX (AAK01935), S. venezuelae; AzicU3 (ADB02840), Kibdelosporangium sp. MJ126NF4; GdmX (AAO06915), S. hygroscopicus; HbmX (AAY28224), S. hygroscopicus; MmyY (WP_011039529.1), S. coelicolor; KinX (AAO65342), S. murayamaensi.

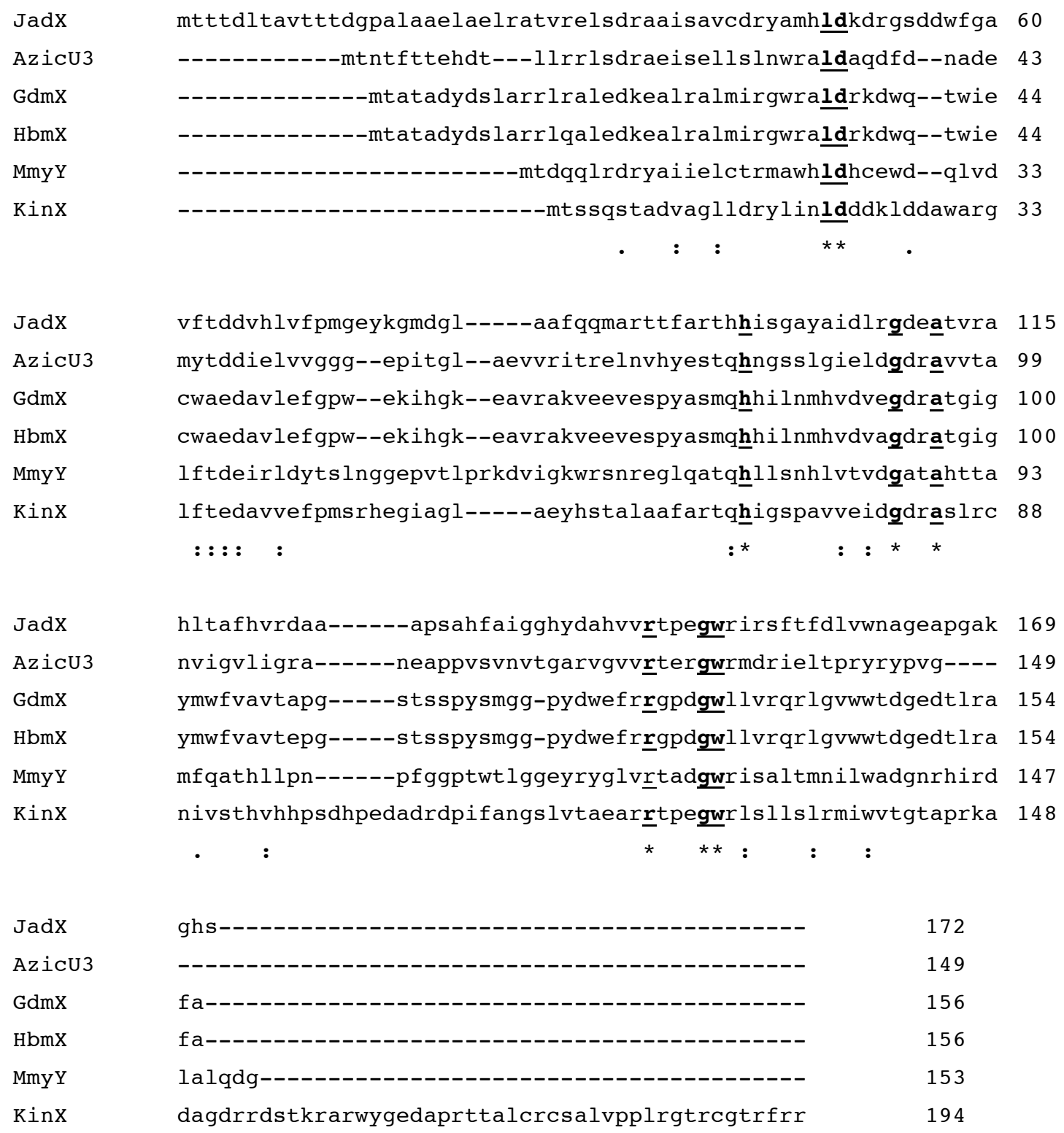




\section{Fig. S3.}

(A) Cellular growth curves $\left(\mathrm{OD}_{600}\right)$ of $S$. venezuelae ISP5230 WT (•), S. venezuelae ISP5230 VS1099 (•), and S. venezuelae ISP5230 VS1085 ( $\mathbf{\Delta})$ ethanol shocked and grown in MSM-Ile medium; $(B)$ absorbance of clarified growth media at $\lambda=526 \mathrm{~nm}\left(\mathrm{Abs}_{526}\right)$, estimating coloured compound production of $S$. venezuelae ISP5230 WT (•), S. venezuelae ISP5230 VS1099 (•), and S. venezuelae ISP5230 VS1085 ( $\Delta$ ) ethanol shocked and grown in MSM-Ile medium; (C) standard curve (linear region) generated from LC-MSMS analysis of jadomycin B; $(D)$ final jadomycin B concentrations from S. venezuelae ISP5230 WT (black), S. venezuelae ISP5230 VS1099 (grey), and S. venezuelae ISP5230 VS1085 (white) after 48 hours growth as determined by LC-MSMS analysis.

A

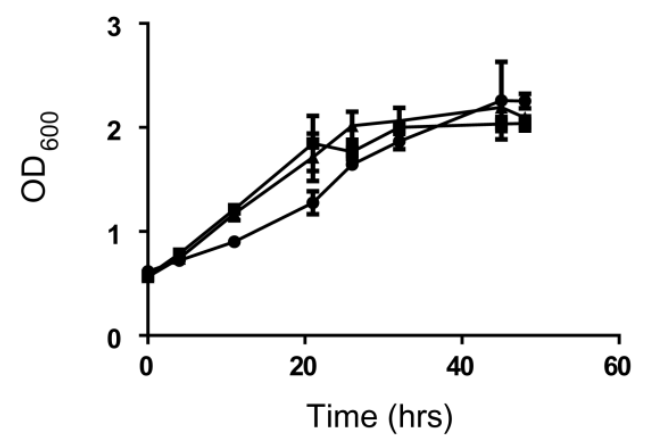

C

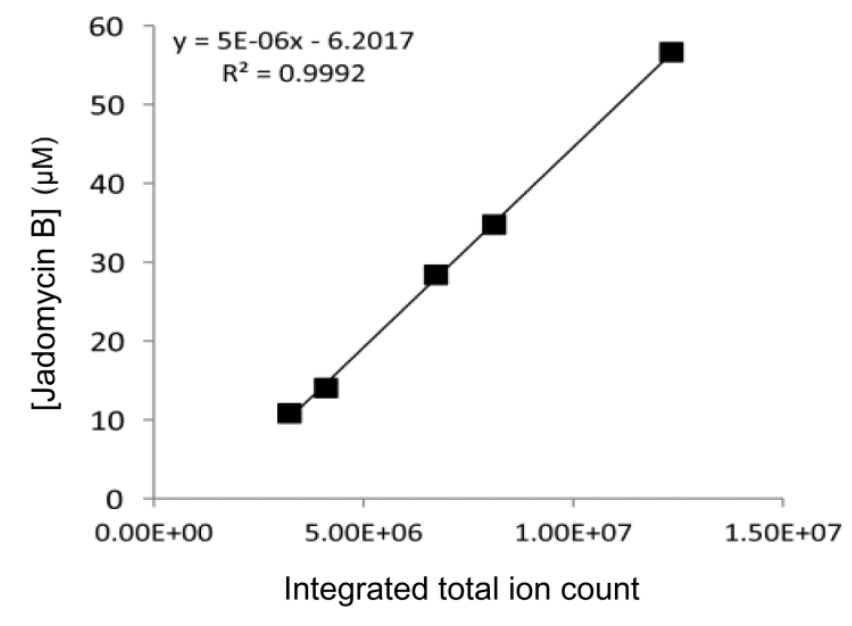

B

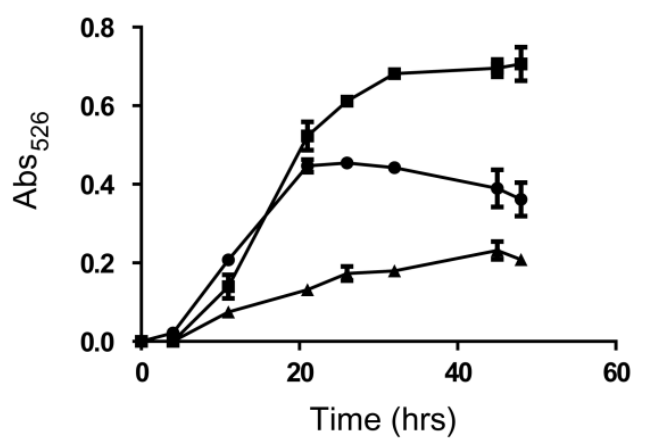

D

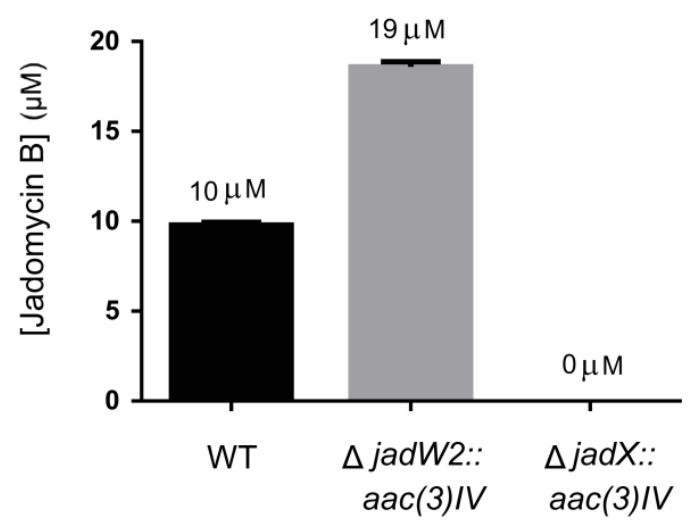




\section{Fig. S4.}

LC-MS/MS standard curves (linear regions) of Jadomycin DS (left) and chloramphenicol (right).
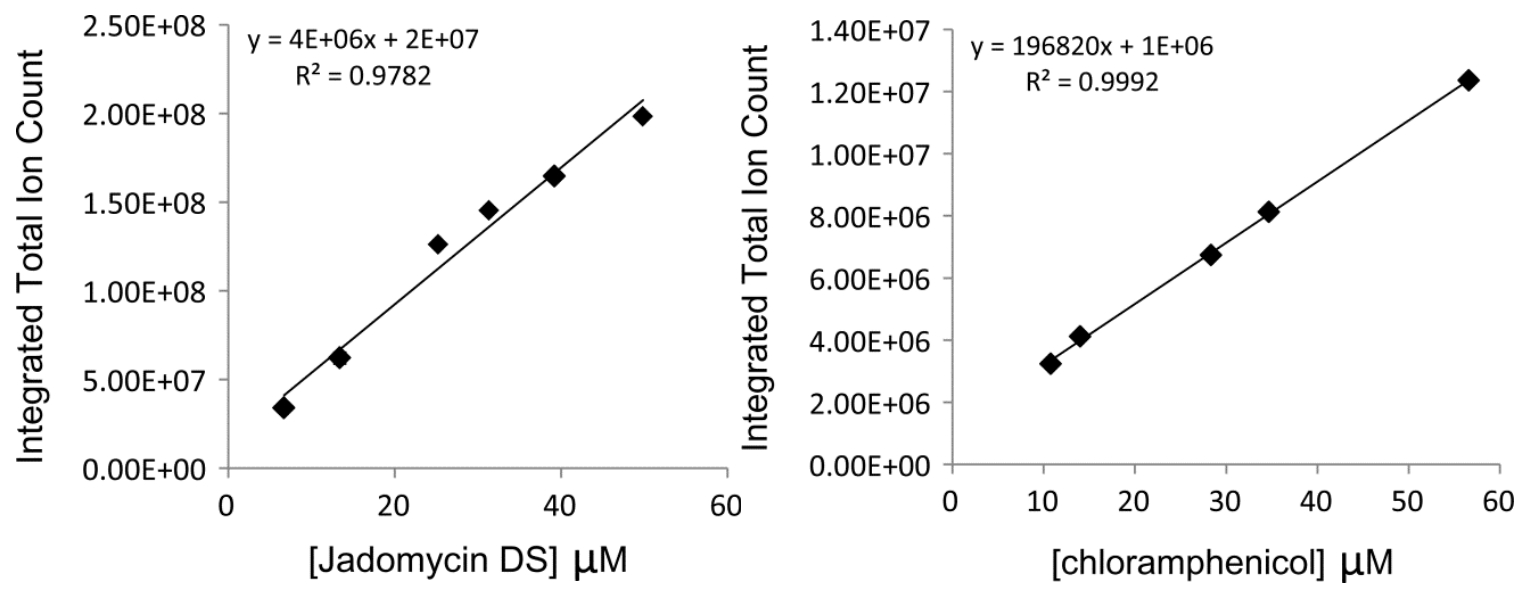

Fig S5.

SDS-PAGE gel of JadX purification showing (A) Broad Range Prestained Protein Marker 7-175 $\mathrm{kDa}$ (NEB); (B) clear lysate before $\mathrm{Ni}^{2+}$-NTA column; (C) clear lysate after $\mathrm{Ni}^{2+}$-NTA column; (D) pelleted cellular debris after lysis; (E-K) FPLC fractions showing purified JadX.

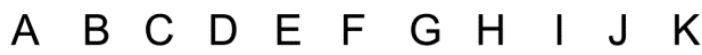

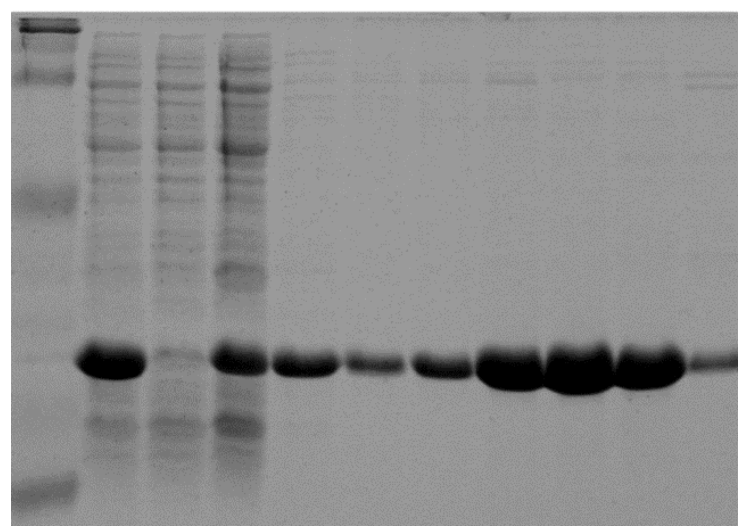




\section{Fig. S6.}

Overlaid negative control WaterLOGSY NMR spectra (10\% dPBS, 85\% PBS, 5\% DMSO-d $\left.{ }_{6}\right)$ in the absence of JadX with varying jadomycin DS concentrations: $(A) 250 \mu \mathrm{M} ;(B) 750 \mu \mathrm{M}$; and (C) $1250 \mu \mathrm{M}$.
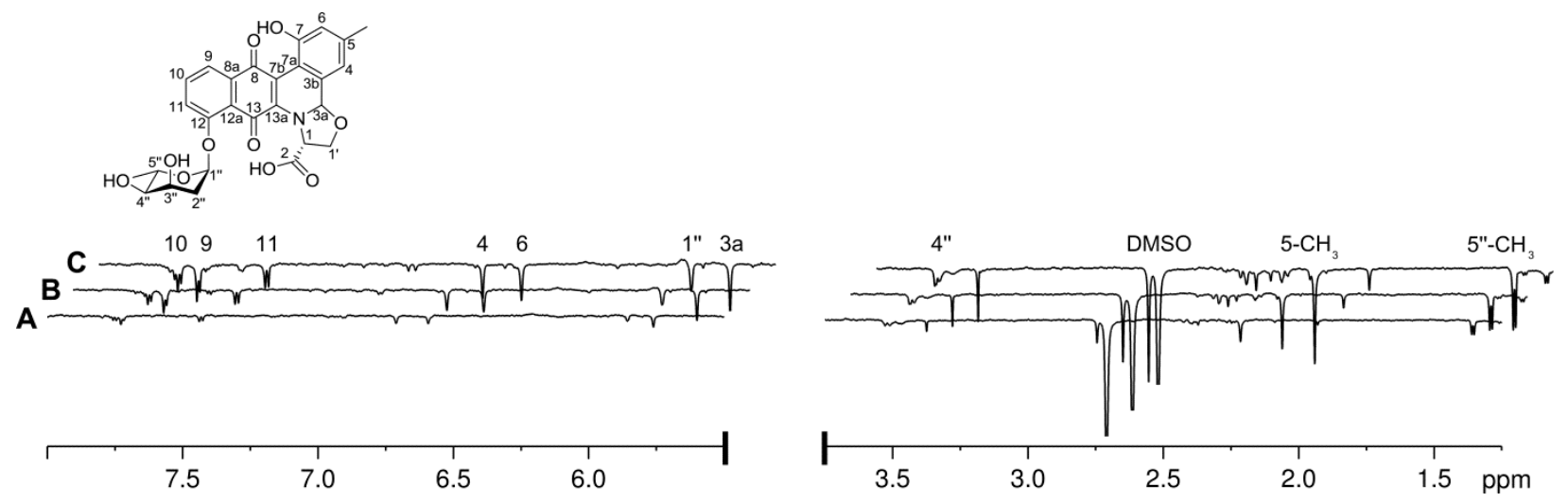

\section{Fig. S7.}

Overlaid WaterLOGSY NMR spectra $\left(10 \% \mathrm{dPBS}, 85 \%\right.$ PBS, 5\% DMSO-d $\left.\mathrm{d}_{6}\right)$ in the presence of $\operatorname{JadX}(10 \mu \mathrm{M})$ with varying jadomycin DS concentrations $(A) 250 \mu \mathrm{M}$; (B) $500 \mu \mathrm{M}$; (C) $750 \mu \mathrm{M}$; and $(D) 1000 \mu \mathrm{M}$.

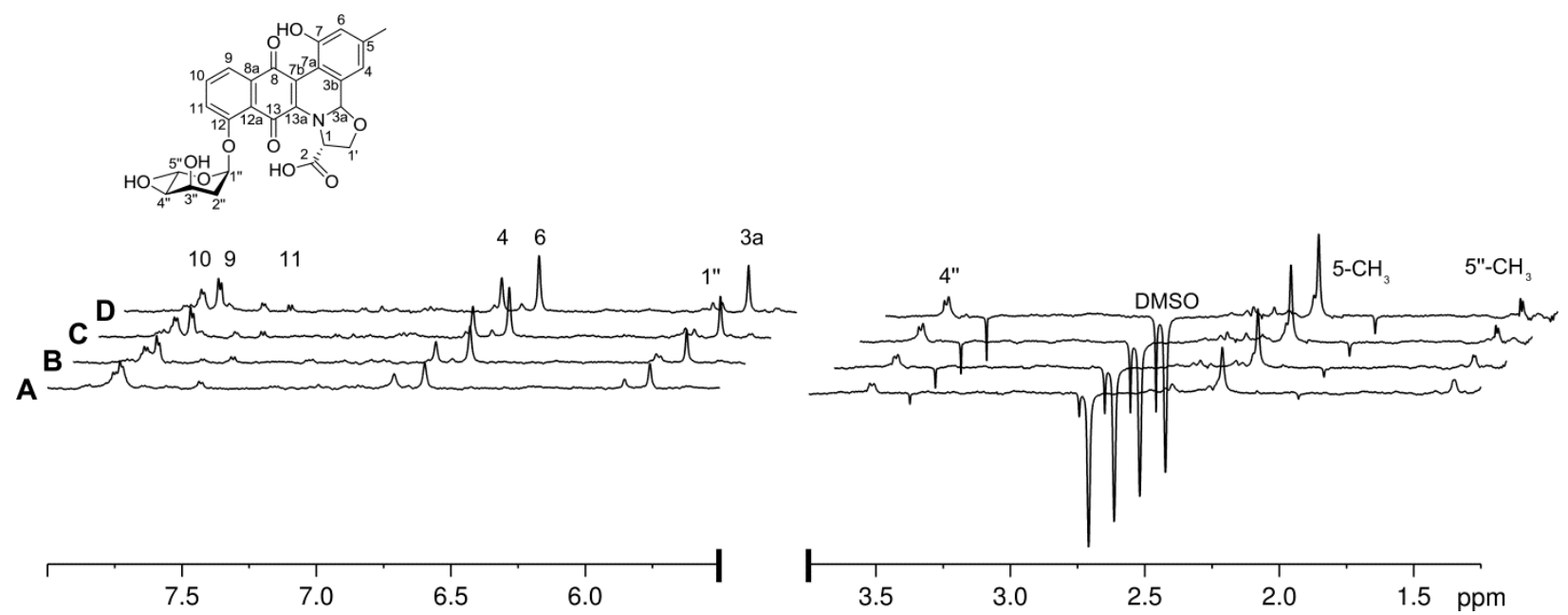




\section{Fig. S8.}

WaterLOGSY generated binding curves of jadomycin DS in the absence of $\operatorname{JadX}(\diamond)$, jadomycin DS in the presence of $\operatorname{JadX}(\boldsymbol{\bullet})$, the difference of the binding and the non-binding standard ( $\boldsymbol{\Delta})$, and the linear fit (solid line). $K_{\mathrm{d}}$ value, in $\mu \mathrm{M}$, is listed. The $\mathrm{Y}$ axis represents NMR signal intensity.
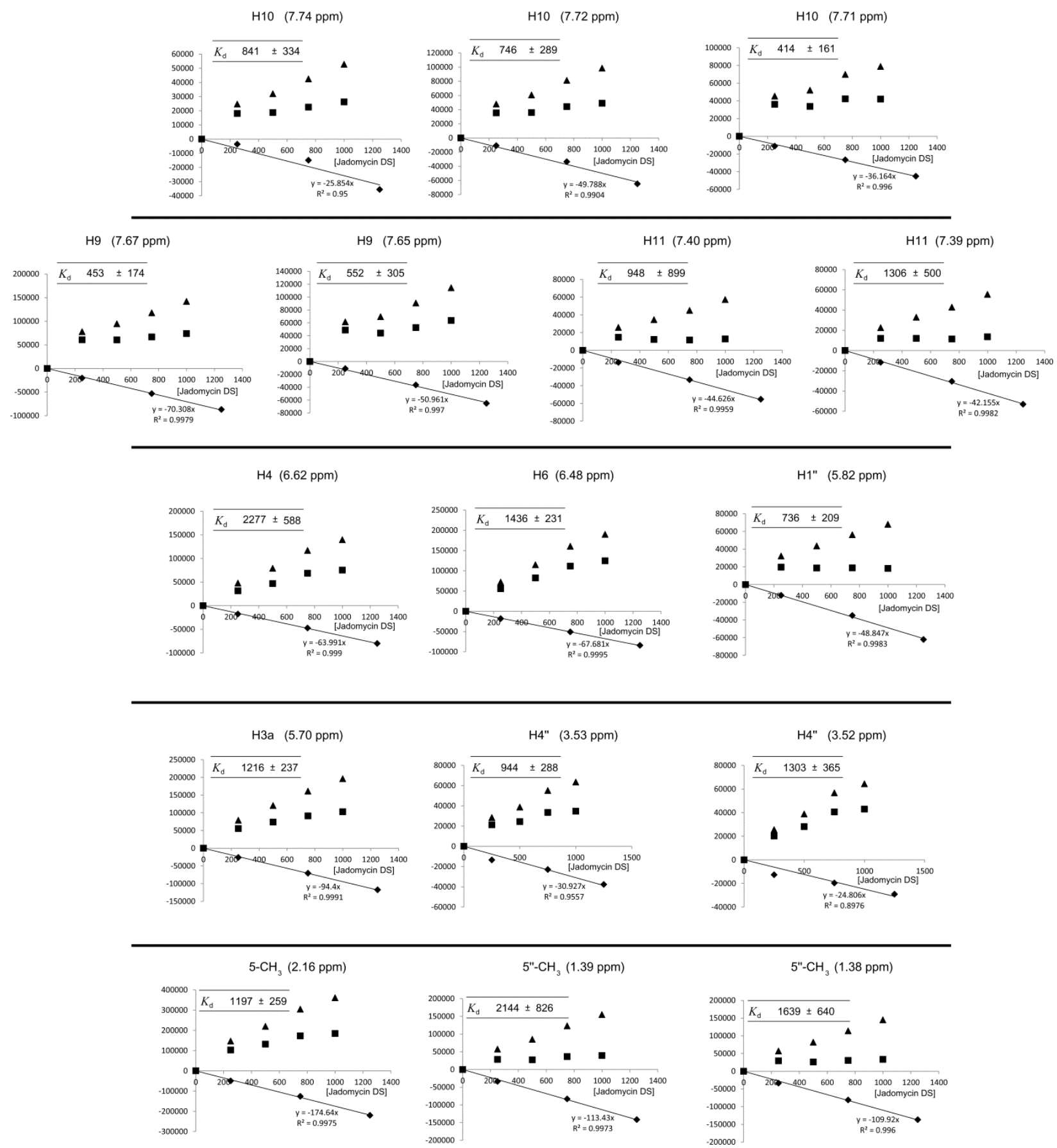


\section{Fig. S9.}

Overlaid negative control WaterLOGSY NMR spectra (10\% dPBS, 85\% PBS, 5\% DMSO-d $\left.\mathrm{d}_{6}\right)$ in the absence of JadX with varying chloramphenicol concentrations: $(A) 237 \mu \mathrm{M}$; $(B) 710 \mu \mathrm{M}$; $(C)$ $1183 \mu \mathrm{M}$; and $(D) 1893 \mu \mathrm{M}$.
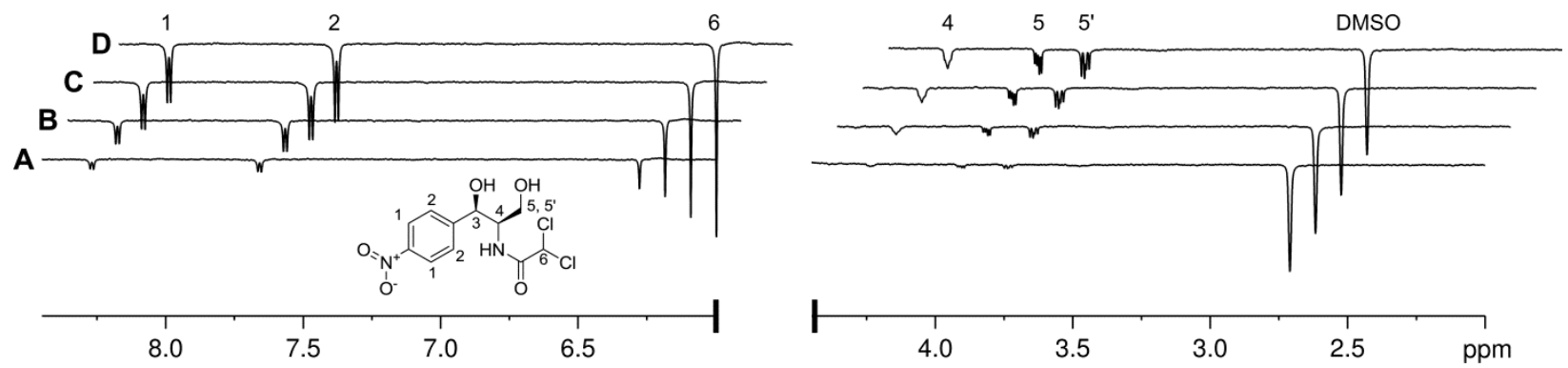

\section{Fig. S10.}

Overlaid WaterLOGSY NMR spectra $\left(10 \%\right.$ dPBS, $85 \%$ PBS, 5\% DMSO-d $\left.\mathrm{d}_{6}\right)$ in the presence of $\operatorname{JadX}(10 \mu \mathrm{M})$ with varying chloramphenicol concentrations $(A) 237 \mu \mathrm{M} ;(B) 473 \mu \mathrm{M}$; (C) 710 $\mu \mathrm{M}$; (D) $947 \mu \mathrm{M}$; (E) $1183 \mu \mathrm{M}$; and $(F) 1420 \mu \mathrm{M}$.

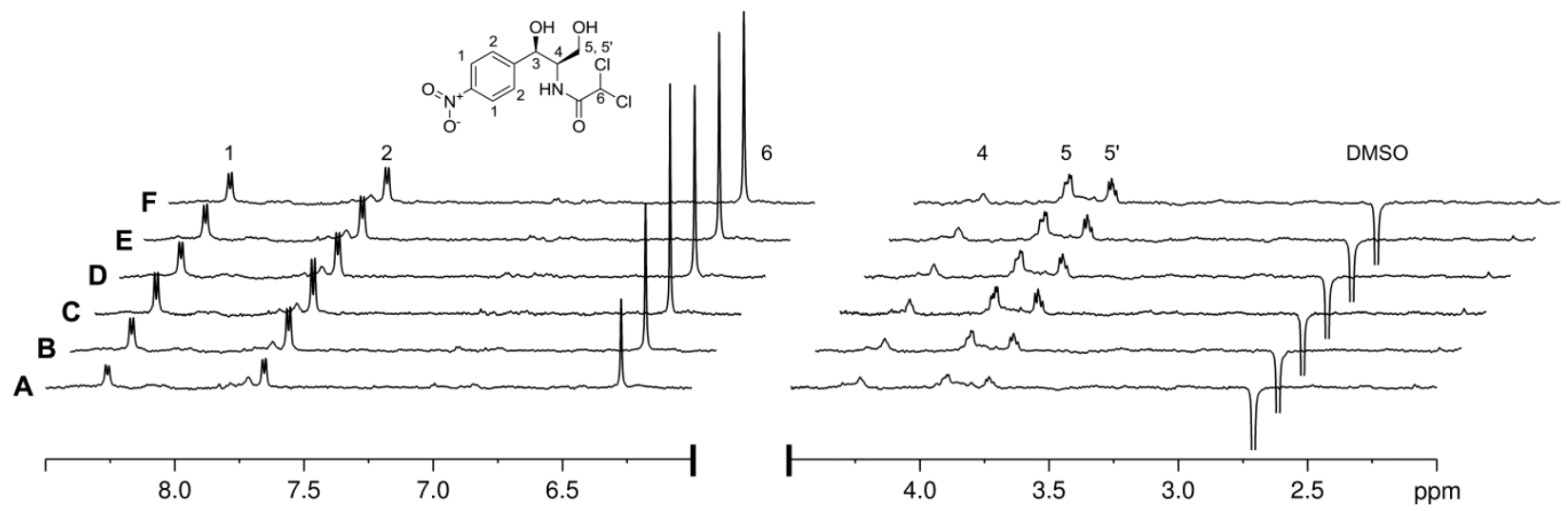




\section{Fig. S11.}

WaterLOGSY generated binding curves of $\mathrm{Cm}$ in the absence of $\operatorname{JadX}(\diamond), \mathrm{Cm}$ in the presence of $\operatorname{JadX}(\boldsymbol{\Xi})$, the difference of the binding and the non-binding standard $(\boldsymbol{\Delta})$, and the linear fit (solid line). $K_{\mathrm{d}}$ value, in $\mu \mathrm{M}$, is listed. The $\mathrm{Y}$ axis represents NMR signal intensity.

$\mathrm{H} 1 \quad(8.27 \mathrm{ppm})$

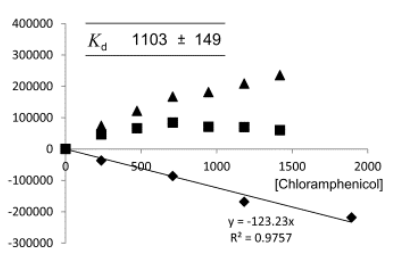

$\mathrm{H} 1 \quad(8.26 \mathrm{ppm})$

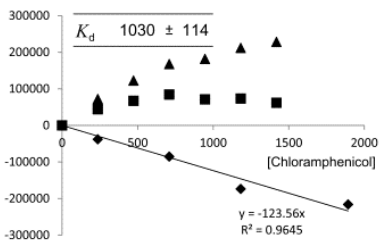

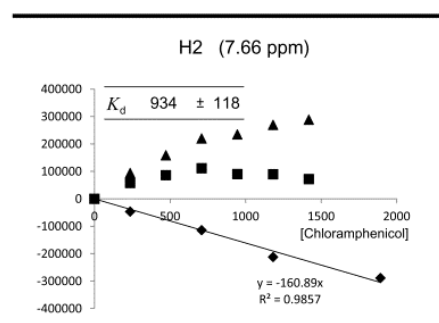

H5 (3.92 ppm)

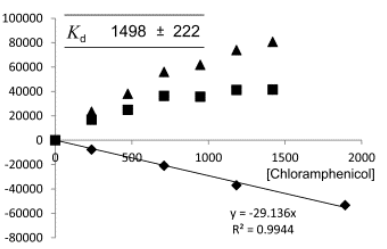

$\mathrm{H}^{\prime} \quad(3.75 \mathrm{ppm})$

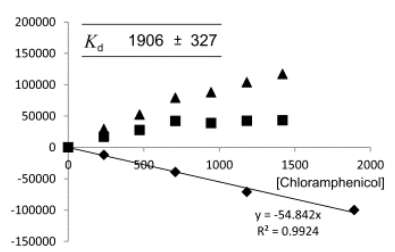

H5 (3.91 ppm)

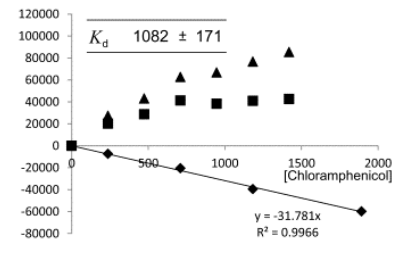

H5' (3.74 ppm)

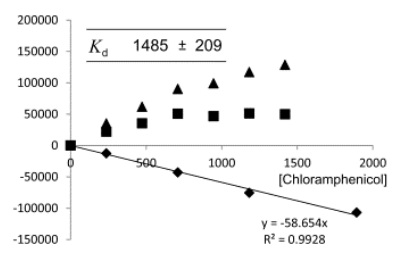

H2 $(7.65 \mathrm{ppm})$

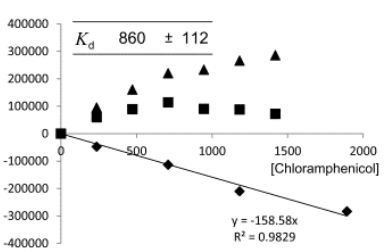

$R^{2}=0.9829$

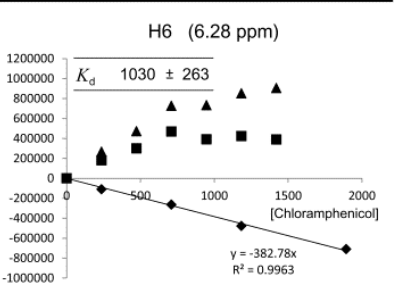

H5 $(3.90 \mathrm{ppm})$
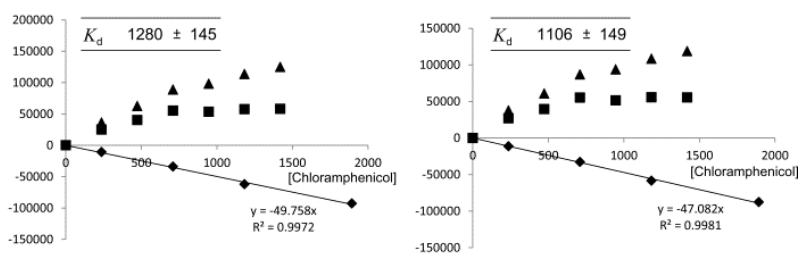

H5' $(3.73$ ppm)

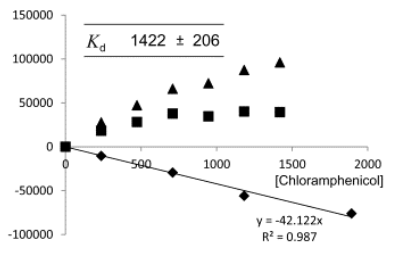

H5' (3.72 ppm)

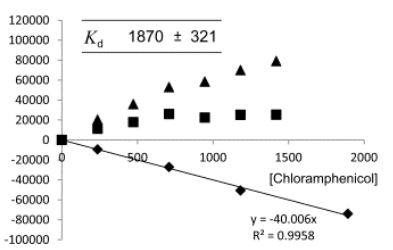




\section{Fig. S12.}

Overlaid negative control WaterLOGSY NMR spectra (10\% dPBS, 85\% PBS, 5\% DMSO-d 6 ) with $\mathrm{Cm}(2000 \mu \mathrm{M})$ in the absence of JadX with varying JdDS concentrations: $(A) 250 \mu \mathrm{M}$; $(B)$ $750 \mu \mathrm{M}$; and (C) $1250 \mu \mathrm{M}$.
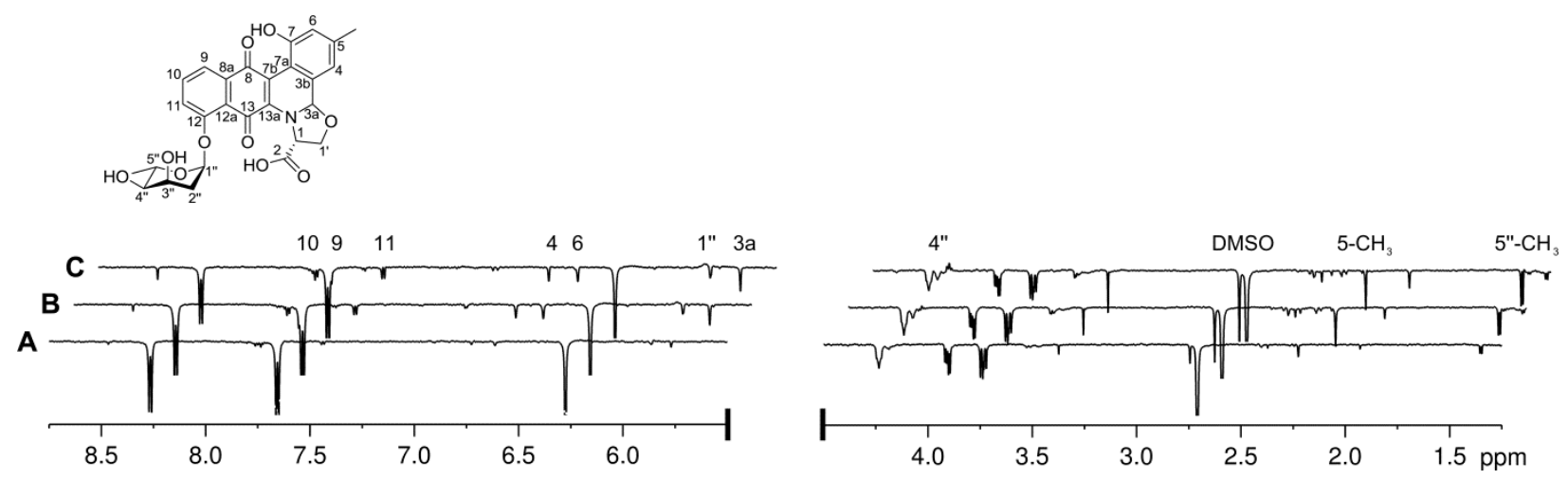

\section{Fig. S13.}

Overlaid WaterLOGSY NMR spectra $\left(10 \% \mathrm{dPBS}, 85 \%\right.$ PBS, 5\% DMSO-d $\left.\mathrm{d}_{6}\right)$ in the presence of $\operatorname{JadX}(10 \mu \mathrm{M})$ and $\mathrm{Cm}(2000 \mu \mathrm{M})$ with varying JdDS concentrations $(A) 250 \mu \mathrm{M}$; (B) $500 \mu \mathrm{M}$; (C) $750 \mu \mathrm{M}$; and (D) $1000 \mu \mathrm{M}$.
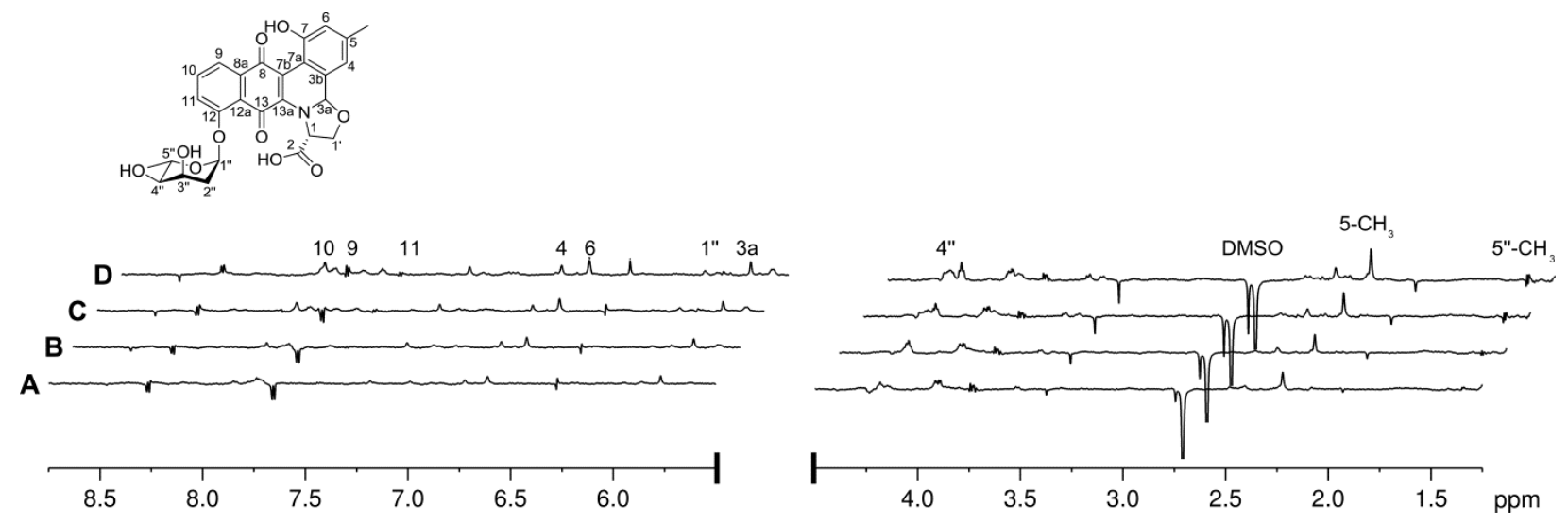

\section{Fig S14.}

WaterLOGSY generated binding curves of JdDS in the presence of Cm $(2000 \mu \mathrm{M})$, in the absence of $\operatorname{JadX}(\diamond)$, in the presence of $\operatorname{JadX}(\boldsymbol{\square})$, the difference of the binding and the non- 
binding standard ( $\boldsymbol{\Delta}$ ), and the linear fit (solid line). $K_{\mathrm{d}}$ value, in $\mu \mathrm{M}$, is listed. The $\mathrm{Y}$ axis represents NMR signal intensity.
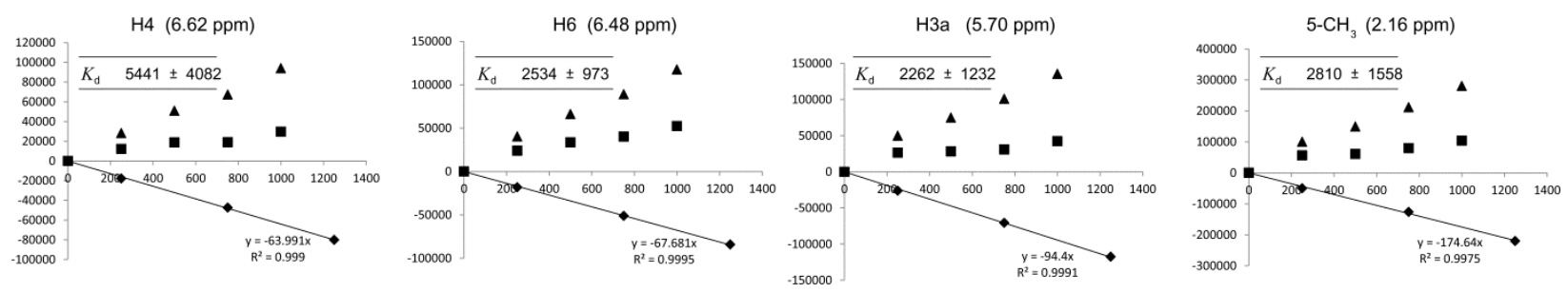

\section{Fig. S15.}

Overlaid negative control WaterLOGSY NMR spectra (10\% dPBS, 85\% PBS, 5\% DMSO-d $\left.\mathrm{d}_{6}\right)$ in the absence of JadX and presence of $1500 \mu \mathrm{M}$ JdDS with varying Cm concentrations: $(A) 250$ $\mu \mathrm{M} ;(B) 750 \mu \mathrm{M}$; and (C) $1500 \mu \mathrm{M}$.
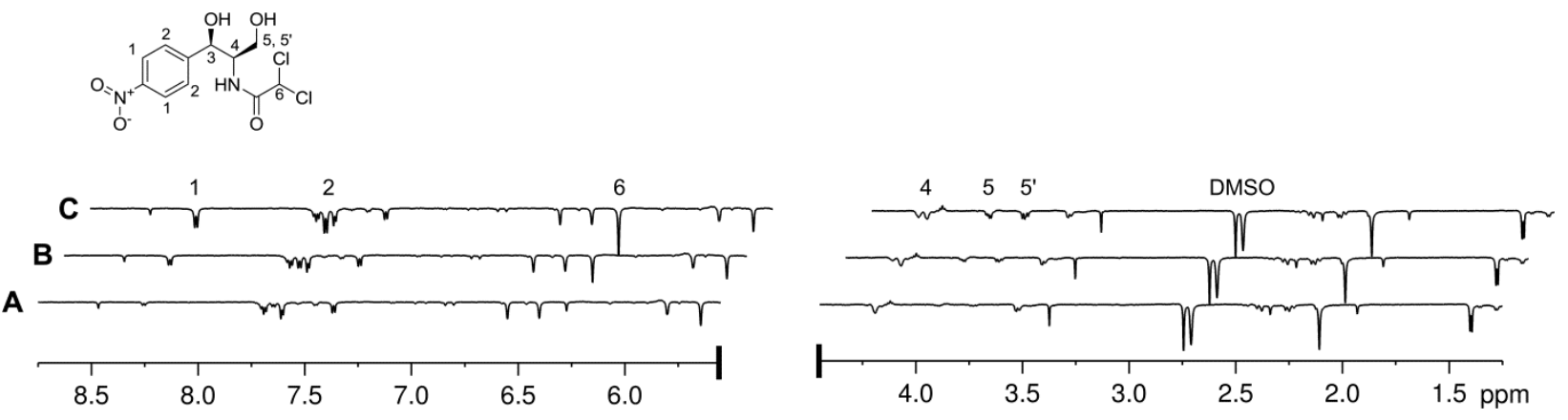

Fig. S16.

Overlaid WaterLOGSY NMR spectra $\left(10 \% \mathrm{dPBS}, 85 \%\right.$ PBS, 5\% DMSO-d $\left.\mathrm{d}_{6}\right)$ in the presence of $\operatorname{JadX}(10 \mu \mathrm{M})$ and JdDS $(1500 \mu \mathrm{M})$ with varying Cm concentrations $(A) 250 \mu \mathrm{M}$; (B) $500 \mu \mathrm{M}$; (C) $750 \mu \mathrm{M}$; (D) $1250 \mu \mathrm{M}$; and (E) $1450 \mu \mathrm{M}$. 


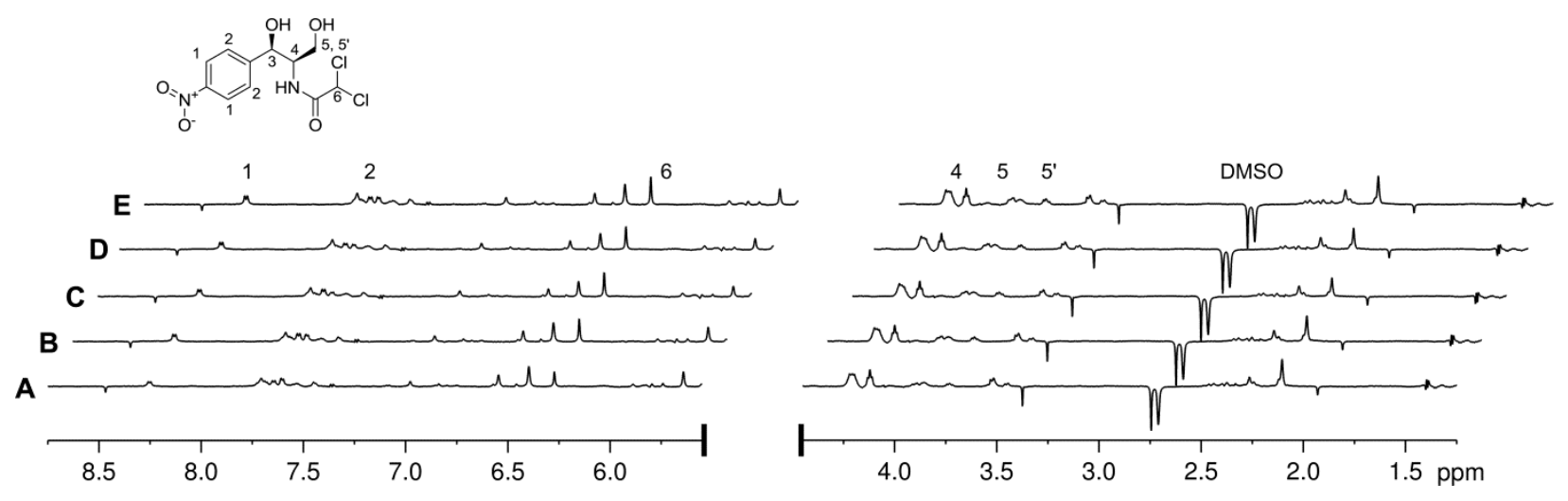

\section{Fig. S17.}

WaterLOGSY generated binding curves of $\mathrm{Cm}$ in the presence of JdDS $(2000 \mu \mathrm{M})$, in the absence of $\operatorname{JadX}(\diamond)$, in the presence of $\operatorname{JadX}(\boldsymbol{\square})$, the difference of the binding and the nonbinding standard ( $\boldsymbol{\Delta})$, and the linear fit (solid line). $K_{\mathrm{d}}$ value, in $\mu \mathrm{M}$, is listed. The $\mathrm{Y}$ axis represents NMR signal intensity.

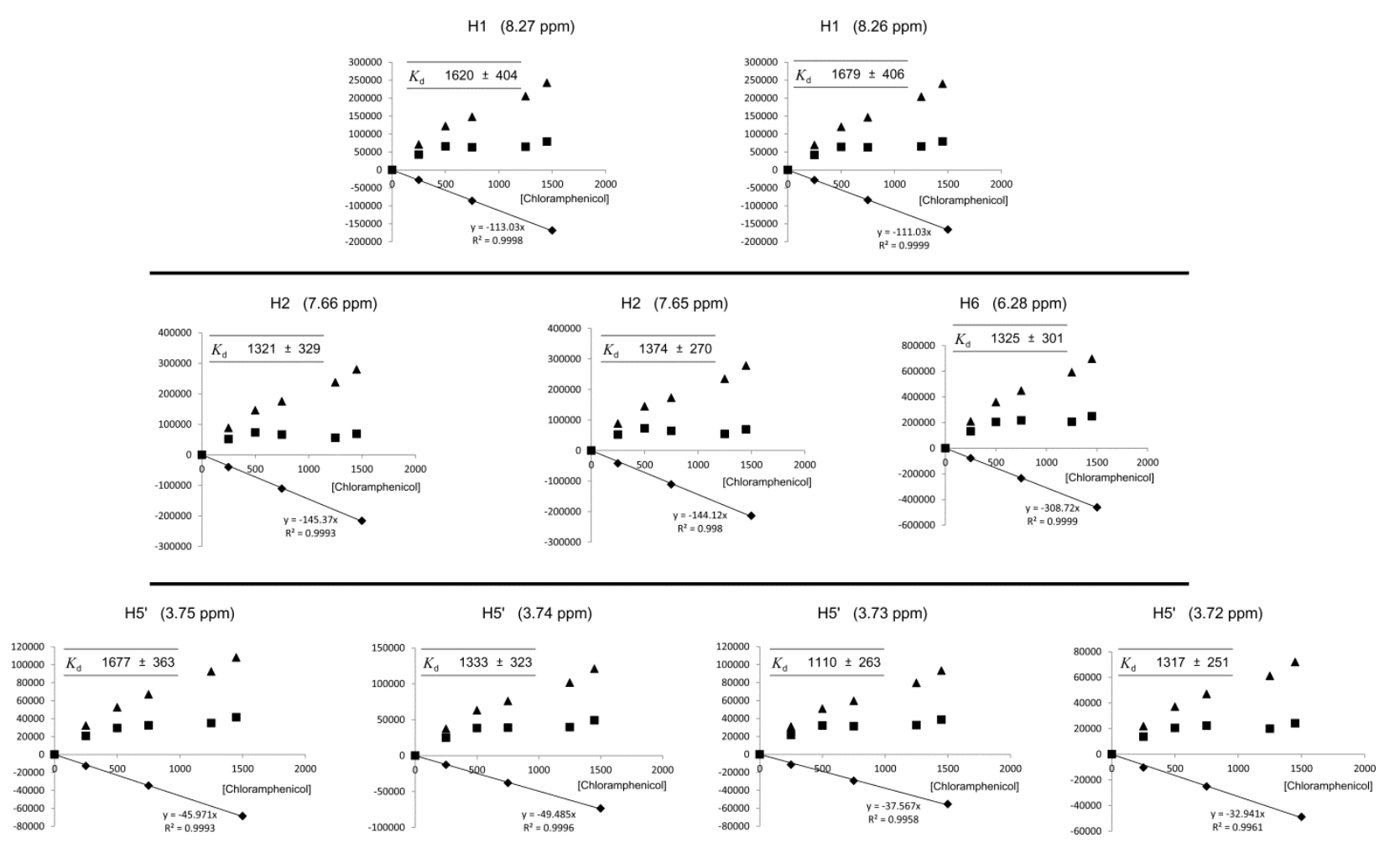




\section{Fig. S18.}

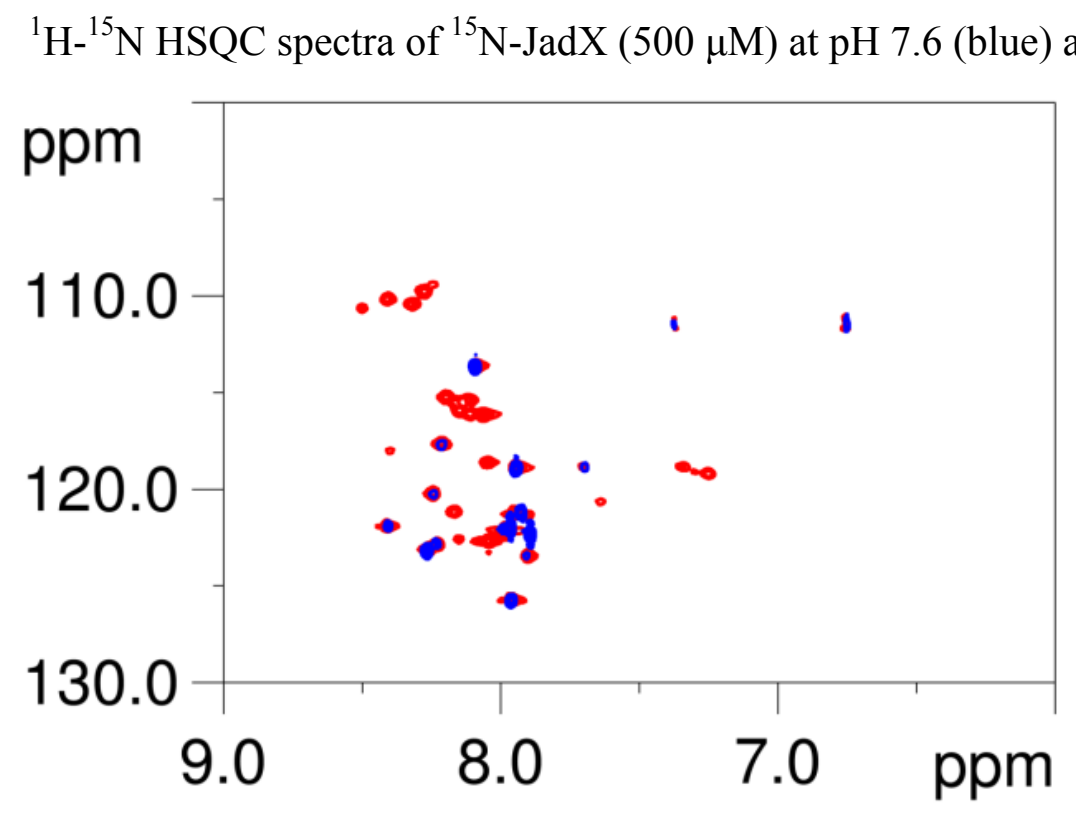

Fig. S19.

WaterLOGSY NMR spectra $(10 \%$ dPBS, 85\% PBS, 5\% DMSO-d 6 ) of Cm $(750 \mu \mathrm{M})$ in the presence of $\operatorname{JadX}(10 \mu \mathrm{M})$ showing similar signal intensities at (A) pH 6.6 and (B) pH 7.6.

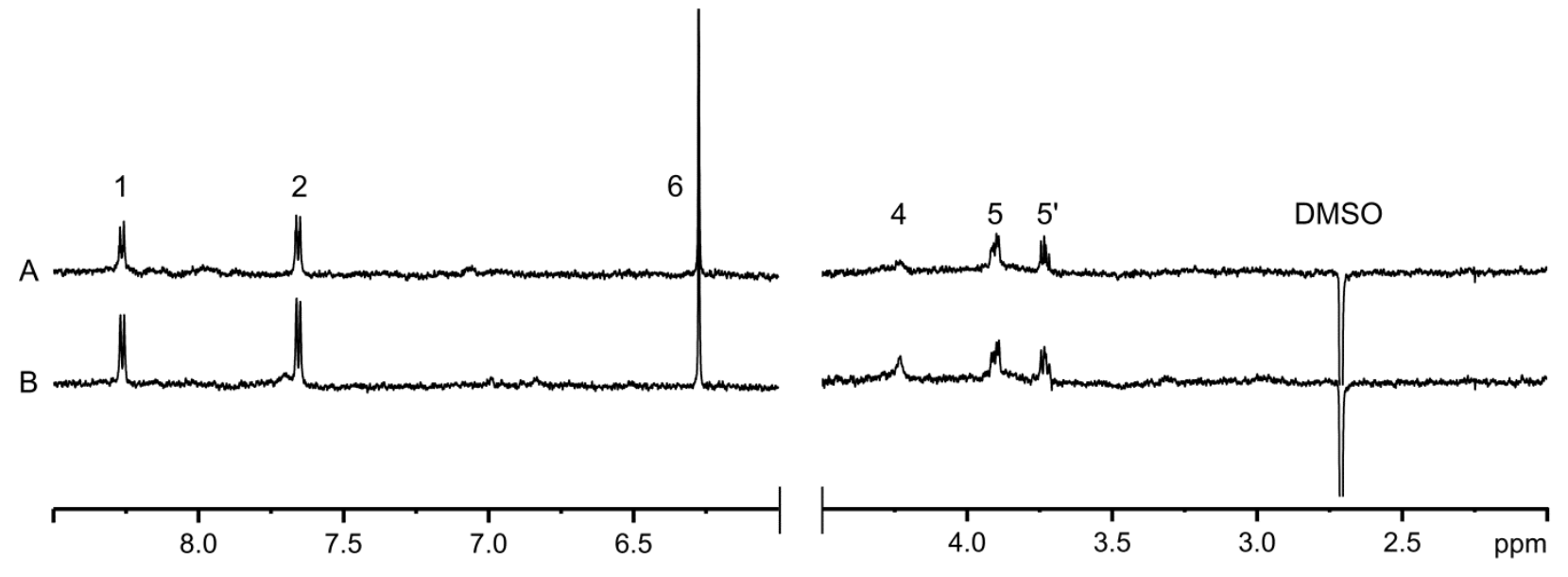




\section{Fig. S20.}

(A) Overlaid ${ }^{15} \mathrm{~N}-{ }^{1} \mathrm{H}$ HSQC spectra for $\operatorname{JadX}(500 \mu \mathrm{M}$, pH 6.6, in the presence of $375 \mu \mathrm{M}$ JdDS with variable $\mathrm{Cm}$ concentrations. Traces show spectra recorded with $100 \mu \mathrm{M}$ (black), $500 \mu \mathrm{M}$ (blue), $1500 \mu \mathrm{M}$ (green) and $2000 \mu \mathrm{M}$ (red) $\mathrm{Cm}$. (B) show the expansion of the indicated region.
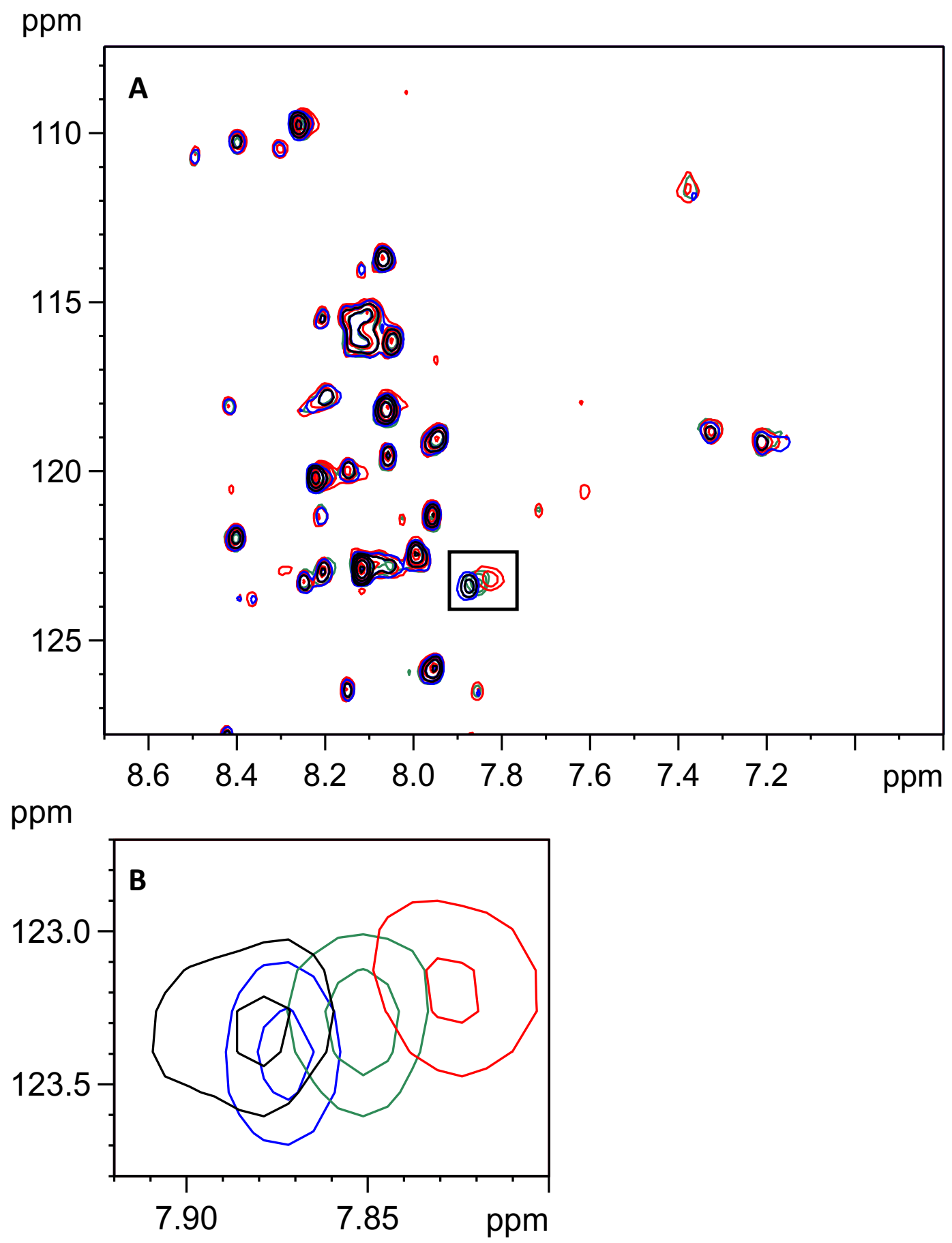


\section{Fig. S21.}

(A) Overlaid ${ }^{15} \mathrm{~N}-{ }^{1} \mathrm{H}$ HSQC spectra of ${ }^{15} \mathrm{~N}-\mathrm{JadX}(500 \mu \mathrm{M}), \mathrm{pH} 6.6$, in the absence of ligand (black), in the presence of $375 \mu \mathrm{M}$ JdDS (blue) and in the presence of both ligands, $375 \mu \mathrm{M}$ JdDS and $2000 \mu \mathrm{M} \mathrm{Cm}$ (red). (B-E) Expansions of indicated regions highlighting cross peaks (15 ) observed to shift in the presence of both ligands from the overlaid spectra shown in $(A)$.
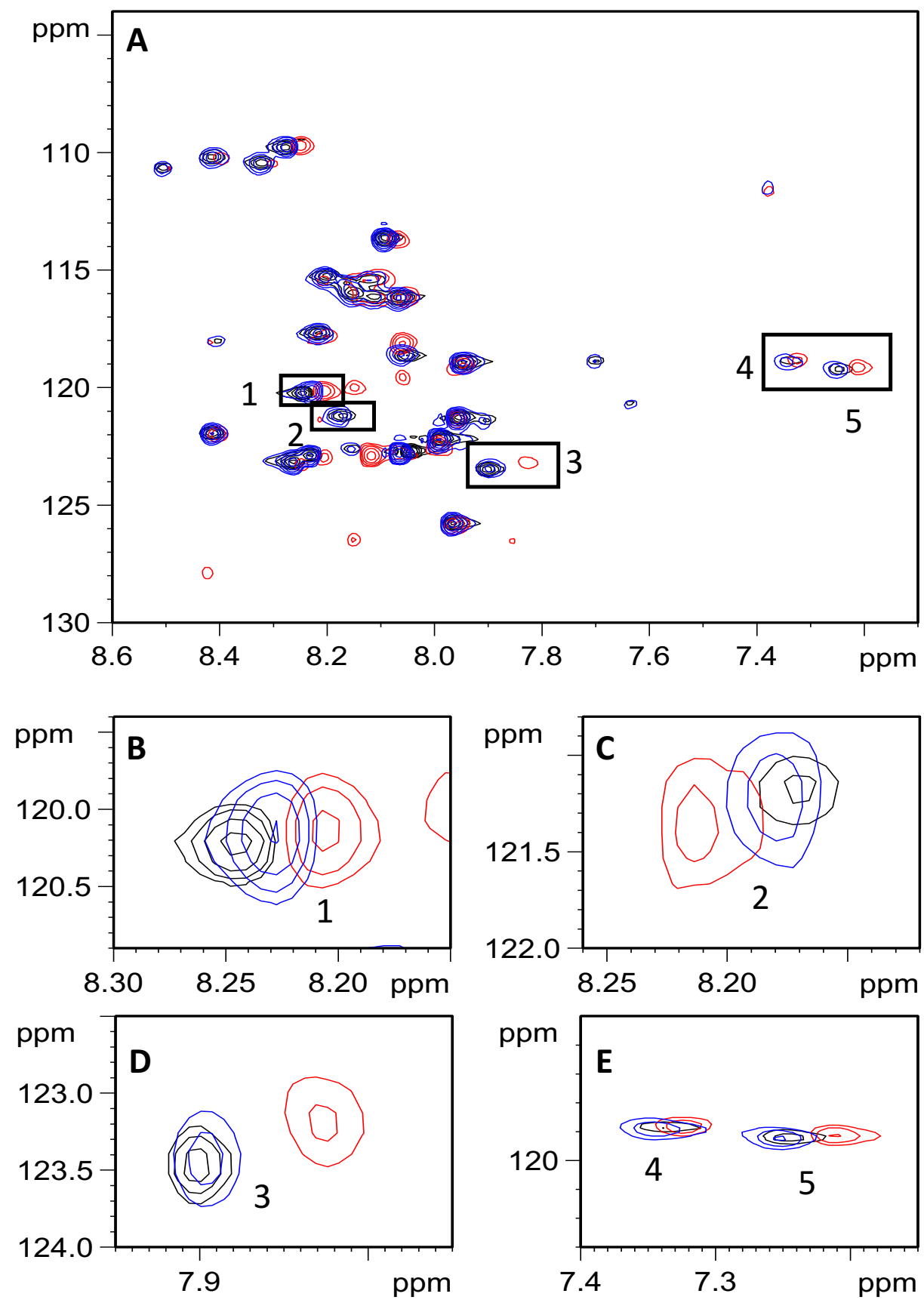
Table S1. Putative and assigned protein functions of jadomycin biosynthetic enzymes and regulatory proteins.

\begin{tabular}{|c|c|c|}
\hline Gene Product & Putative or Assigned Function & Pathway \\
\hline JadA & Ketosynthase alpha subunit & PKS \\
\hline $\mathrm{JadB}$ & Ketosynthase beta subunit & PKS \\
\hline $\mathrm{JadC}$ & Acyl carrier protein & PKS \\
\hline JadD & Cyclase/dehydratase & PKS \\
\hline $\mathrm{JadE}$ & Ketoreductase & PKS \\
\hline JadF & 2,3-Dehydratase & Post-PKS \\
\hline JadG & Oxygenase & Post-PKS \\
\hline $\mathrm{JadH}$ & Oxygenase-dehydrase & Post-PKS \\
\hline JadI & Cyclase & PKS \\
\hline JadJ & Acyl-CoA carboxylase & PKS \\
\hline JadK & Hydrolase & Putative post-PKS \\
\hline JadL & Efflux protein & Efflux \\
\hline JadM & Phosphopantetheinyl transferase & PKS \\
\hline JadN & Acyl-CoA decarboxylase & PKS \\
\hline JadO & Dehydratase & Dideoxysugar synthesis \\
\hline JadP & Ketoreductase & Dideoxysugar synthesis \\
\hline JadQ & Nucleotidyltransferase & Dideoxysugar synthesis \\
\hline JadS & Glycosyltransferase & Dideoxysugar synthesis \\
\hline JadT & 4,6-Dehydratase & Dideoxysugar synthesis \\
\hline JadU & Epimerase & Dideoxysugar synthesis \\
\hline $\mathrm{JadV}$ & Ketoreductase & Dideoxysugar synthesis \\
\hline $\operatorname{JadX}$ & Potential regulator/unknown & Unknown \\
\hline JadY & Flavin-mononucleotide/FAD reductase & Cofactor synthesis \\
\hline JadR1 & OmpR-type atypical response & Regulation \\
\hline JadR2 & $\begin{array}{l}\text { "Pseudo" } \gamma \text {-butyrolactone } \\
\text { receptor }\end{array}$ & Regulation \\
\hline JadR3 & $\begin{array}{l}\gamma \text {-butyrolactone } \\
\text { receptor }\end{array}$ & Regulation \\
\hline $\mathrm{JadR}^{*}$ & TetR family regulator & Regulation \\
\hline JadW1 & $\gamma$-butyrolactone signal synthesis & Regulation \\
\hline JadW2 & $\gamma$-butyrolactone signal synthesis & Regulation \\
\hline JadW3 & $\gamma$-butyrolactone signal synthesis & Regulation \\
\hline
\end{tabular}


Table S2. Jadomycin DS NMR data recorded in dPBS.

\begin{tabular}{|c|c|c|c|c|c|}
\hline \begin{tabular}{|l|} 
Position \\
\end{tabular} & $\delta^{1} \mathbf{H}(\mathrm{ppm})$ & Multiplicity $(\mathrm{J}(\mathrm{Hz}))$ & $\delta^{13} \mathrm{C}(\mathrm{ppm})$ & $\cos Y$ & HMBC \\
\hline 1 & 5.22 & $\mathrm{t}(7.7)$ & 63.2 & $1^{\prime}$ & $2,3 a, 1^{\prime}$ \\
\hline 2 & & & 175.6 & & \\
\hline $3 a$ & 5.54 & $\mathrm{~s}$ & 89.1 & None & 4 \\
\hline $3 b$ & & & Unobserved & & \\
\hline 4 & 6.44 & $s$ & 115.9 & $5-\mathrm{CH}_{3}, 6$ & $3 a, 5-\mathrm{CH}_{3}, 6,7 \mathrm{a}$ \\
\hline 5 & & & 141.8 & & \\
\hline $5-\mathrm{CH}_{3}$ & 2.01 & $s$ & 21.8 & 4,6 & $4,5,6$ \\
\hline 6 & 6.26 & $s$ & 120.0 & $4,5-\mathrm{CH}_{3}$ & $4,5-\mathrm{CH}_{3}, 7,7 \mathrm{a}$ \\
\hline 7 & & & 152.4 & & \\
\hline \multicolumn{6}{|l|}{ 7-OH } \\
\hline $7 a$ & & & 111.7 & & \\
\hline $7 b$ & & & Unobserved & & \\
\hline 8 & & & 180.7 & & \\
\hline $8 a$ & & & Unobserved & & \\
\hline 9 & 7.63 & $d(7.6)$ & 121.8 & 10 & $8,11,12 a$ \\
\hline 10 & 7.60 & $t(8.1)$ & 137.3 & 9,11 & 11,12 \\
\hline 11 & 7.28 & bd (8.5) & 120.0 & 10 & $9,10,12,12 a, 13$ \\
\hline 12 & & & 155.9 & & \\
\hline $12 a$ & & & 118.8 & & \\
\hline 13 & & & 183.0 & & \\
\hline $13 a$ & & & Unobserved & & \\
\hline $1^{\prime}$ & 4.05 & $t(7.8)$ & 71.5 & $1,1^{\prime}$ & $1,2,3 a$ \\
\hline $1^{\prime}$ & 4.91 & $t(8.4)$ & 71.5 & $1,1^{\prime}$ & $1,2,3 a$ \\
\hline $1^{\prime \prime}$ & 5.71 & $d(2.5)$ & 97.2 & $2^{\prime \prime}$ & $12,3^{\prime \prime}, 5^{\prime \prime}$ \\
\hline $2^{\prime \prime}$ & 2.18 & $\mathrm{dt}(15.1,3.3)$ & 36.0 & 1", 3" & None \\
\hline $2^{\prime \prime}$ & 2.33 & $\mathrm{dd}(15.1,2.8)$ & 36.0 & 1", 3" & $3^{\prime \prime}, 4^{\prime \prime}$ \\
\hline $3^{\prime \prime}$ & 4.14 & $\mathrm{~m}$ & 67.9 & 2", 4" & $1^{\prime \prime}$ \\
\hline \multicolumn{6}{|l|}{ 3"-OH } \\
\hline $4 "$ & 3.47 & $\mathrm{dd}(10.0,3.0)$ & 73.7 & $3^{\prime \prime}, 5^{\prime \prime}$ & 5", 5"--CH \\
\hline \multicolumn{6}{|l|}{ 4"-OH } \\
\hline $5 "$ & 4.18 & $\mathrm{~m}$ & 66.4 & $4^{\prime \prime}, 5^{\prime \prime}-\mathrm{CH}_{3}$ & None \\
\hline 5"-CH & 1.36 & $d(6.2)$ & 18.7 & $5 "$ & $4^{\prime \prime}, 5^{\prime \prime}$ \\
\hline
\end{tabular}


Table S3. Tabulated $K_{\mathrm{d}}$ values for $\mathrm{Cm}$ and JdDS binding JadX

\begin{tabular}{|c|c|c|c|c|c|}
\hline $\begin{array}{c}\text { Cm NMR } \\
\text { assigned } \\
\text { peak }\end{array}$ & $\begin{array}{c}\mathrm{Cm} K_{\mathrm{d}} \\
(\mu \mathrm{M})\end{array}$ & $\begin{array}{l}\text { Cm } K_{\mathrm{d}}(\mu \mathrm{M}) \\
\text { with } \operatorname{JdDS}^{a}\end{array}$ & $\begin{array}{c}\text { JdDS } \\
\text { NMR } \\
\text { assigned } \\
\text { peak }\end{array}$ & $\begin{array}{c}\mathrm{JdDS} K_{\mathrm{d}} \\
(\mu \mathrm{M})\end{array}$ & $\begin{array}{c}\text { JdDS } K_{\mathrm{d}}(\mu \mathrm{M}) \\
\text { with } \mathrm{Cm}^{b}\end{array}$ \\
\hline $\begin{array}{l}\text { Total } \\
\text { Avg. }^{c}\end{array}$ & $1181 \pm 161$ & $\mathrm{~N} / \mathrm{A}$ & $\begin{array}{l}\text { Total } \\
\text { Avg. }^{c}\end{array}$ & $1217 \pm 395$ & $\mathrm{~N} / \mathrm{A}$ \\
\hline 1 & $1070 \pm 133$ & $1649 \pm 405$ & $3 a$ & $1216 \pm 237$ & $2262 \pm 1232$ \\
\hline 2 & $897 \pm 114$ & $1323 \pm 312$ & 6 & $1436 \pm 231$ & $2534 \pm 973$ \\
\hline $5^{\prime}$ & $1240 \pm 272$ & $1359 \pm 306$ & 4 & $2277 \pm 588$ & $5441 \pm 4082$ \\
\hline 6 & $1670 \pm 263$ & $1374 \pm 270$ & $5-\mathrm{CH}_{3}$ & $1197 \pm 259$ & $2810 \pm 1558$ \\
\hline Avg. ${ }^{d}$ & $1219 \pm 208$ & $1426 \pm 327$ & Avg. $^{e}$ & $1532 \pm 361$ & $3262 \pm 2321$ \\
\hline
\end{tabular}

${ }^{a} K_{\mathrm{d}}$ values associated with $\mathrm{JadX}$ binding $\mathrm{Cm}$ in the presence of JdDS $(1500 \mu \mathrm{M}) ;{ }^{b} K_{\mathrm{d}}$ values associated with JadX binding JdDS in the presence of $\mathrm{Cm}(2000 \mu \mathrm{M})$; ${ }^{c}$ total average is representative of the average $K_{\mathrm{d}}$ value for all measurable peaks for an individual ligand (Figure 4 and 5); ${ }^{d}$ average $K_{\mathrm{d}}$ values associated with $\mathrm{Cm}$ in the presence of JadDS calculated from peaks 1 , 2, 5', and 6; ${ }^{e}$ average $K_{\mathrm{d}}$ values associated with JdDS in the presence of Cm calculated from peaks $3 \mathrm{a}, 4,6$, and $5-\mathrm{CH}_{3}$.

\section{Equations}

Equation S1 was used to calculate waterLOGSY $K_{\mathrm{d}}$ values, as derived in reference. ${ }^{4}$

$\mathrm{I}=\frac{-\mathrm{I}_{\max }}{1+\left(\frac{\mathrm{L}}{K_{\mathrm{D}}}\right)}+\mathrm{I}_{\max }$

Equation S2 was used to calculate chemical shift $K_{\mathrm{d}}$ values, as derived in reference. ${ }^{5}$

$\delta$ obs $=\Delta \delta \max ([P] \mathrm{t}+L] \mathrm{t}+K \mathrm{D}-[([P] \mathrm{t}+[L] \mathrm{t}+K \mathrm{D}) 2-4[P] \mathrm{t}[L] \mathrm{t}] 1 / 22[P] \mathrm{t}$

\section{References}

1 C. N. Borissow, C. L. Graham, R. T. Syvitski, T. R. Reid, J. Blay and D. L. Jakeman, ChemBioChem, 2007, 8, 1198-1203.

2 J. Marley, M. Lu and C. Bracken, J. Biomol. NMR, 2001, 20, 71-75.

3 H. E. Gottlieb, V. Kotlyar and A. Nudelman, J. Org. Chem., 1997, 62, 7512-7515. 
4 C. Dalvit, G. Fogliatto, A. Stewart, M. Veronesi and B. Stockman, J. Biomol. NMR, 2001, 21, 349-359.

5 M. P. Williamson, Prog. Nucl. Magn. Reson. Spectrosc., 2013, 73, 1-16. 